ZAPISKI HistoryCZNe t. 86, 2021, z. 3, s. 81-116

ISSN 0044-1791

http://dx.doi.org/10.15762/ZH.2021.24

KRZYSZTOF KWIATKOWSKI*

(iD) https://orcid.org/0000-0003-1827-3122

\title{
BUDOWNICTWO WAROWNE \\ JAKO NARZĘDZIE INTENSYFIKACJI WŁADZTWA NA OBRZEŻACH KRAJU \\ Casus BezŁaWeK W Późnośredniowiecznych Prusach
}

\author{
Abstract \\ Constructing Strongholds \\ as a Means of Strengthening Territorial Authority on Peripheries: \\ The Case of the Castle in Bäslack (Bezławki) \\ in Late Medieval Prussia
}

The article concerns the chronological framework and circumstances of constructing a castle of the Teutonic Order in Bäslack (Bezławki). The research was based on written, mainly manuscript, primary sources. A detailed analysis has been made of the colonisation carried out by the Teutonic Order in the lower and middle course of the Dajna River, where this castle was built, in the region of Barten (Bartia). The analysis made it possible to date back the chronology of constructing the stronghold to the 1370 s. It was also argued that the direct reason for erecting the castle was the conflict of the Bishop of Ermland (Warmia) Johann II Stryprock with the Teutonic Order, which had been escalating in the 1360s, and which ended only in 1374/1375. On the one hand, the construction of the castle in Bäslack was to symbolically emphasise the dominant position of the Teutonic Order in Prussia and its supremacy over the dominion of the bishops of Ermland. On the other hand, it was to serve as a tangible demarcation of the territory which was directly under the rule of the Teutonic Order in the region, where the border between the lands controlled by the Teutonic Knights and by the bishops of Ermland had not been firmly established, which was one of the causes of the aforementioned conflict.

Keywords: late Middle Ages; Prussia; Ermland; Warmia; Teutonic Order; castles; territorial authority; fortifications; conflicts; colonisation

\footnotetext{
* Instytut Historii i Archiwistyki, Uniwersytet Mikołaja Kopernika w Toruniu

(@) Krzysztof.Kwiatkowski@umk.pl
}

Nadesłany 24.01.2020; Nadesłany po poprawkach 6.07.2021; Zaakceptowany 8.07.2021 
W opublikowanym w 2016r. artykule dotyczącym wildhausu w Bezławkach (Bayselauken, niem. Bäslack) ${ }^{1}$, powstałym na marginesie uwag recenzyjnych do publikacji prezentującej wyniki badań archeologicznych zamku przeprowadzonych w latach $2008-2012^{2}$, podjęto trzy zespoły zagadnień związanych $\mathrm{z}$ funkcjonowaniem tego obiektu jako dzieła fortyfikacyjnego (punktu umocnionego, warowni). Przeanalizowana została w nim (a) problematyka rozmaitych militarnych funkcji zamku, następnie przeprowadzona (b) krytyka przypisywanego warowni funkcjonowania jako element rzekomego systemu obronnego na obszarze środkowej i południowej Barcji w XIV oraz na początku XV w., a wreszcie podjęto (c) zagadnienie typologii morfologicznej obiektów warownych nazywanych „wildhausami”, do której to kategorii zaliczyć można zamek bezławecki. Te trzy aspekty historii tej warowni nie wyczerpują jednakże całej istotnej problematyki z nią związanej. Niniejszy tekst dotyczy dwóch innych kwestii, równie ważnych jak poprzednie, nie tylko z lokalnego punktu widzenia samych Bezławek, lecz także w szerszym: regionalnym, jak również ogólnopruskim kontekście. Przedmiotem prezentowanych tu analiz i rozważań są mianowicie problematyka związków budownictwa warownego z działaniami osadniczymi na przylegających do siebie obszarach późnośredniowiecznej, „zakonnej”-Barcji i „biskupiej” Warmii (a ściślej terenach pierwotnie „biskupiej” Barcji) oraz pytanie o możliwe konkretne przyczyny wzniesienia zamku w Bezławkach, $z$ jednoczesnym uwzględnieniem problematycznych kwestii chronologicznych dotyczących jego budowy.

\section{BUDOWNICTWO WAROWNE A DZIAŁANIA OSADNICZE}

W kontekście podjętych w 2016 r. rozważań o systemowości funkcjonowania obiektów fortyfikacyjnych w Prusach pojawia się ważki problem wzajemnych związków między działalnością osadniczą a budownictwem warownym w tym kraju. W przypadku bowiem zamku w Bezławkach mamy do czynienia z punktem umocnionym wzniesionym wedle ogólnych szacunków zapewne w ostatniej tercji XIV w. w rejonie wówczas aktywnie zasiedlanym. Mimo rozległych studiów i bogatej literatury dotyczącej z jednej strony osadnictwa w późnośredniowiecznych Prusach ${ }^{3}, \mathrm{z}$ drugiej zaś wznoszenia obiektów

${ }^{1}$ Krzysztof Kwiatкowsкi, (Wild)haus w Bezławkach (Bayselauken, Bäslack) - uwagi na temat budownictwa warownego zakonu niemieckiego w późnośredniowiecznych Prusach, Zapiski Historyczne, t. 81: 2016, z. 2, s. 7-44.

${ }^{2}$ Bezławki - ocalić od zniszczenia. Wyniki prac interdyscyplinarnych prowadzonych $w$ latach 2008-2011, red. Arkadiusz Koperkiewicz (Gdańskie Studia Archeologiczne, nr 3), Gdańsk 2013.

${ }^{3}$ Syntetycznie o tym zob. Wiesław DŁUGokęcki, Kolonizacja ziemi chetmińskiej, Prus i Pomorza Gdańskiego do 1410 r., [in:] Państwo zakonu krzyżackiego w Prusach. Władza i społeczeństwo, red. Marian Biskup, Roman CzAjA, Warszawa 2008, s. 200-217; idem, Odbudowa osadnictwa, kolonizacji i przemiany wsi w państwie krzyżackim (1411-1525), [in:] ibid., s. 375-383. Spośród studiów analitycznych por. Karl KAsIske, Die Siedlungstätigkeit des Deutschen Ordens 
warownych ${ }^{4}$, niektóre aspekty obustronnych zależności tych fenomenów nie zostały dotychczas dokładnie przebadane, ani w poszczególnych przypadkach, ani w szerszym ujęciu. Jako zasadnicze jawi się tu pytanie o pierwszeństwo jednej z tych dwóch form ludzkiej działalności w konkretnej okolicy, mianowicie na terenach wchodzących w obręb (staro)pruskiej krainy Barcji, rozciągających się nad ówczesną górną Sajną (niem. Zaine), a także Młynówką (niem. Mühlen-Fließ), Izerą (niem. Eyserfließ) i rzeką Wilkenflys (późn. pol. Wilczka, ob. pol. Cyna) $)^{5}$ oraz nad środkową Dajną (niem. Deine), nieopodal której brzegu wzniesiony został zamek w Bezławkach.

Duże znaczenie zamków w akcji osadniczej w łacińskim kręgu kulturowym, w tym także w krajach niemieckojęzycznych i na obszarach objętych ekspansją bądź wpływem wytworzonych tam wzorów kulturowych i wzorów kultury, w okresie zarówno tzw. pełnego, jak również tzw. późnego średniowiecza, jest fenomenem dobrze już rozpoznanym w piśmiennictwie historycznym i nie musi tu być dokładniej prezentowane ${ }^{6}$. Wystarczy w ogólności

im östlichen Preußen bis zum Jahre 1410 (Einzelschriften der Historischen Kommission für ostund westpreußische Landesforschung, Bd. 5), Königsberg i. Pr. 1934.

${ }^{4} \mathrm{Z}$ najnowszych studiów por. Sławomir JóźwiAk, Janusz TrupindA, Krzyżackie zamki komturskie $w$ Prusach. Topografia i układ przestrzenny na podstawie średniowiecznych źródeł pisanych, Torun 2012; Tomasz Torbus, Die Konventsburgen im Deutschordensland Preußen (Schriften des Bundesinstituts für ostdeutsche Kultur und Geschichte, Bd. 11), München 1998; toż samo z drobnymi uaktualnieniami: idem, Zamki konwentualne państwa krzyżackiego w Prusach, Gdańsk 2014; idem, Zamki krzyżackie, tł. Łukasz Bieniasz, Wrocław 2010; Maria Sp£AWsKA-Korczak, Zamek krzyżacki w Świeciu. Próba rekonstrukcji zamku wysokiego w średniowieczu, Toruń 2014. Por. też monografie zbiorowe: Zamek w Grudziądzu w świetle badań archeologicznoarchitektonicznych. Studia i materiały, red. Marcin WiewIóRA, Toruń-Grudziądz 2012; Zamek biskupów chetmińskich $w$ Wąbrzeźnie w świetle badań archeologiczno-architektonicznych. Studia i materiały, red. Marcin WiewiónA, Toruń 2014; Zamek krzyżacki w Toruniu XIII-XXI w. Studium historyczno-architektoniczne z katalogiem detalu architektonicznego ze zbiorów Muzeum Okregowego, red. Elżbieta Pilecka, Zbigniew Nawrocki, Romualda UziembŁo, Jadwiga ŁuKASZEWICZ, Toruń 2017.

${ }^{5}$ W kwestii hydronimii okolic Reszla zob. Robert KLIMEK, Między prawdą a zmyśleniem... Trzy błędy historyczne z dziejów Reszla, [in:] Reszel. 680 lat historii miasta, red. Grzegorz BIAŁUŃSKI, Robert KlimeK, Reszel 2018, s. 213-238, tu s. 221-229, 236-238 (przypisy).

${ }^{6}$ Literatura dotycząca władczych (politycznych) funkcji zamków, zarówno tych budowanych przez władców, jak i panów spośród arystokracji i szlachty czy panów duchownych, jest obecnie bardzo obszerna, stąd uzasadnione wydaje się przywołanie jedynie ważniejszych ujęć syntetyzujących dotyczących niemieckiego kręgu językowego i strefy środkowoeuropejskiej, do których zaliczają się Prusy. Por. Ebner Herwig, Die Burg als Forschungsproblem mittelalterlicher Verfassungsgeschichte, [in:] Die Burgen im deutschen Sprachraum. Ihre rechts- und verfassungsgeschichtliche Bedeutung, hrsg. v. Hans Patze (Vorträge und Forschungen, Bd. 19, Tl. 1), Sigmaringen 1976, s. 11-82, tu s. 27-30, 56-61, 64-67; Dieter Kerber, Die Burg als Element des Landesausbaues, [in:] Burgen in Mitteleuropa. Ein Handbuch, Bd. 2: Geschichte und Burgenlandschaften, Stuttgart 1999, s. 68-72; idem, Burgenpolitik, [in:] ibid., s. 73-78; idem, Die Burg als Herrschaftszentrum, [in:] ibid., s. 82-89; Hans K. Schulze, Grundstrukturen der Ver- 
wskazać, że zamki jako budowle wielofunkcyjne oddziaływały wieloaspektowo na działalność osadniczą. Uwarunkowania władcze z reguły warunkowały to, czy owo oddziaływanie było w konkretnym przypadku pozytywne czy też negatywne. Wrogi zamek, którego zarządca i stojąca do jego dyspozycji zbrojna załoga oraz różnego rodzaju słudzy mogli kontrolować okoliczne tereny, był w stanie hamować, czy wręcz uniemożliwiać ich zagospodarowywanie. Z kolei własna warownia mogła stać się podstawą bądź katalizatorem lokalnego melioratio terre, tj. zasiedlania i zagospodarowywania danej okolicy wedle norm, zasad i rozwiązań umożliwiających intensywniejszą aniżeli dotychczas eksploatację terenu i szerzej całego geośrodowiska ${ }^{7}$. Natomiast bardzo rzadko

fassung im Mittelalter, Bd. 2: Familie, Sippe und Geschlecht, Haus und Hof, Dorf und Mark, Burg, Pfalz und Königshof, Stadt, Stuttgart-Berlin-Köln 2000, s. 101-104; Hans Patze, Die Burgen in Verfassung und Recht des deutschen Sprachraumes, [in:] Die Burgen im deutschen Sprachraum. Ihre rechts- und verfassungsgeschichtliche Bedeutung, hrsg. v. Hans PATZE (Vorträge und Forschungen, Bd. 19, Tl. 2), Sigmaringen 1976, s. 421-441, tu s. 429-435; Werner Hechberger, Adel, Ministerialität und Rittertum im Mittelalter (Enzyklopädie deutscher Geschichte, Bd. 72), München 2004, s. 21, 77-78; Ernst SCHUberT, Fürstliche Herrschaft und Territorium im späten Mittelalter (Enzyklopädie deutscher Geschichte, Bd. 35), München 2006, s. 16-17. W większości tych publikacji podano najważniejszą starszą literaturę. Zaś z bardziej analitycznych studiów zob. np. Hans-Martin Maurer, Burgen, [in:] Die Zeit der Staufer. Geschichte - Kunst - Kultur. Katalog der Ausstellung, Bd. 3: Aufsätze, Stuttgart 1977, s. 119-128, tu s. 119-121; Wolf-Rüdiger BERNs, Burgenpolitik und Herrschaft des Erzbischofs Balduin von Trier (1307-1354) (Vorträge und Forschungen, Sonderbd. 27), Sigmaringen 1980; Bernd FeHRENBACH, Die Burgenpolitik der Landgrafen von Hessen im Spätmittelalter (1263-1413) (Schriften des Hessischen Landesamtes für geschichtliche Landeskunde, Bd. 42), Marburg 2012, tu zwłaszcza s. 4-6, 15-17, 21, 44-47, 58-59, 70-71, 268-269; Christian Оттевsвасн, Die Burgen der Herren und Grafen von Hanau (1166-1642). Studien zur Burgenpolitik und Burgenarchitektur eines Adelshauses (Hanauer Geschichtsblätter, Bd. 51), Neustadt/Aisch 2018, tu zwłaszcza s. 60, 64-69, 71, 118. Dla Prus aktualne pozostaje gruntowne studium: Friedrich BenNinghoven, Die Burgen als Grundpfeiler des spätmittelalterlichen Wehrwesens im preußisch-livländischen Deutschordenstaat, [in:] Die Burgen im deutschen Sprachraum. Ihre rechts- und verfassungsgeschichtliche Bedeutung, hrsg. v. Hans PATZE (Vorträge und Forschungen, Bd. 19, Tl. 1), Sigmaringen 1976, s. 565-601, w tym zwłaszcza s. 576-580 (tu zaprezentowane różnorodne funkcje zamków zakonnych); por. też Reinhard Wenskus, Das Ordensland Preußen als Territorialstaat des 14. Jahrhundert, [in:] Der deutsche Territorialstaat im 14. Jahrhundert, Bd. 1, hrsg. v. Hans PATze (Vorträge und Forschungen, Bd. 13/1), Sigmaringen 1970, s. 347-382, tu s. 350-351; to samo zob. idem, Das Ordensland Preußen als Territorialstaat des 14. Jahrhundert, [in:] idem, Ausgewählte Aufsätze zum frühen und preußischen Mittelalter. Festgabe zu seinem 70. Geburtstag, hrsg. v. Hans Patze, Sigmaringen 1986, s. 317-352, tu s. 320-321; zob. też Marian ArszyŃski, Budownictwo warowne zakonu krzyżackiego w Prusach (1230-1454), Toruń 1995, s. 198-199; idem, Architektura warowna zakonu krzyżackiego w Prusach, [in:] Fundacje artystyczne na terenie państwa krzyżackiego w Prusach. Katalog wystawy w Muzeum Zamkowym w Malborku 25 czerwca - 12 września 2010 roku, t. 2: Eseje, red. Barbara Pospieszna, Malbork 2010, s. 7-45, tu s. 25-27.

${ }^{7}$ Por. gruntowne studium porównawcze: Peter ErLen, Europäischer Landesausbau und mittelalterliche deutsche Ostsiedlung. Ein struktureller Vergleich anhand von drei exemplarisch ausgewählten Siedelregionen (Historische und landeskundliche Ostmitteleuropa-Studien, Bd. 9), 
w literaturze przedmiotu dotyczącej Prus zauważany jest drugi kierunek relacji między zamkami a osadnictwem, wyrażający się m.in. w tym, że warownie $\mathrm{z}$ reguły (aczkolwiek nie zawsze) potrzebowały pewnego zaplecza gospodarczego oraz oparcia na strukturach osadniczych i społecznych (w kontekście pełnionych przez nie funkcji militarnych), co z kolei często (choć znowu nie zawsze) warunkowało ich zależność od lokalnych warunków demograficznych.

Arkadiusz Koperkiewicz w swoim artykule z 2013 r. wskazał, że w przypadku obszarów Barcji punktem wyjściowym zagospodarowywania tej krainy przez zakon niemiecki była budowa „linii zamków w Gierdawach, Barcianach, Sątocznie i Kętrzynie". Dopiero w okolicach nowo wzniesionych punktów warownych rozwijało się jego zdaniem „osadnictwo wojskowe” oraz zakładano „wsie chłopskie”. Podobnie Seweryn Szczepański podkreślał uprzednie zakładanie zamków zakonnych na obszarach środkowej i południowo-wschodniej części Barcji, tj. w Leunenburgu (ob. pol. Sątoczno), Rastenburgu (ob. pol. Kętrzyn) i Rynie (niem. Rhein), wokół których „lokowano dobra rycerskie różnej wielkości" i dopiero od ok. 1370 r. rozpoczęła się akcja zakładania wsi czynszowych ${ }^{9}$. Obraz ukazany zwłaszcza przez S. Szczepańskiego nie jest bynajmniej niewłaściwy, jednak wydaje się nieco spłaszczony chronologicznie, uogólniony przestrzennie (kategorią geograficzną pozostaje środkowa i południowowschodnia część Barcji), a przede wszystkim oparty na niepogłębionej względem starszej literatury analizie osadniczej. Dla dokładniejszego nakreślenia i zrozumienia mechanizmów oraz uwarunkowań działań osadniczych należałoby operować głównymi interwałami czasowymi równymi mniej więcej aktywności jednego pokolenia (20-25 lat), uwzględniając przy tym wszelkie nadzwyczajne czynniki mogące wpływać na dynamikę fenomenów demograficzno-osadniczych.

W dorzeczu przepływającej przez tereny barckie rzeki Guber (niem. Guber), na obszarach podległych od $1326 \mathrm{r}$. coraz bardziej realnej kontroli zakonu niemieckiego, można wskazać w pierwszej połowie XIV w. przynajmniej

Marburg/Lahn 1992; oraz poświęconą tzw. niemieckiej kolonizacji wschodniej pracę: Charles Higounet, Die deutsche Ostsiedlung im Mittelalter, übers. v. Mafred VAsold, Berlin 1986; syntetycznie zaś m.in. Michael Borgolte, Europa entdeckt seine Vielfalt 1050-1250 (Handbuch der Geschichte Europas, Bd. 3), Stuttgart 2002, s. 235; Robert Bartlett, Tworzenie Europy. Podbój, kolonizacja i przemiany kulturowe 950-1350, tł. Grażyna Waluga, Poznań 2003, s. 202-252.

${ }^{8}$ Arkadiusz Koperkiewicz, Zamek $w$ Bezławkach $w$ świetle badań archeologicznych, [in:] Bezławki - ocalić od zniszczenia. Wyniki prac interdyscyplinarnych prowadzonych $w$ latach 2008-2011, red. Arkadiusz Koperkiewicz (Gdańskie Studia Archeologiczne, nr 3), Gdańsk 2013, s. $44-74$, tu s. 44.

${ }^{9}$ Seweryn Szczepański, Bezławki i okolice w kontekście osadniczym plemiennej Barcji oraz kętrzyńskiego okręgu prokuratorskiego w średniowieczu, [in:] Bezławki - ocalić od zniszczenia. Wyniki prac interdyscyplinarnych prowadzonych w latach 2008-2011, red. Arkadiusz KoPERKIEwICZ (Gdańskie Studia Archeologiczne, nr 3), Gdańsk 2013, s. 14-37, tu s. 23. 
dwa wyraźne etapy aktywności osadniczej, między którymi zarysowuje się pewien zastój. Pierwszy etap przypadł na okres bezpośrednio następujący po podziale Barcji między biskupów warmińskich a Zakon ustalonym w 1326 r. ${ }^{10}$ i był, jak się wydaje, ściśle związany z budową w środkowej części „zakonnej” Barcji (rozpoczętą [?] w 1325 i 1326 r.) zamków Bartenburg (niem. Barten, ob. pol. Barciany) ${ }^{11}$ i Leunenburg (ob. pol. Sątoczno) ${ }^{12}$. Również w północnej

${ }^{10}$ Geheimes Staatsarchiv Preußischer Kulturbesitz, Berlin, XX. Hauptabteilung (dalej cyt. GStA PK, XX. HA), Ordensfolianten (dalej cyt. OF), Nr. 270a, fol. 6r-6v, 105r-105v; GStA PK, XX. HA, OF, Nr. 271, fol. 22r-22v, 104r, 160r. Edycja z pierwszego odpisu w OF 271: Codex diplomaticus Warmiensis oder Regesten und Urkunden zur Geschichte Ermlands (dalej cyt. CDW), Bd. 1: Urkunden der Jahre 1231-1340, hrsg. v. Carl P. WoELKy, Johann M. SAAGE (Monumenta Historiae Warmiensis oder Quellensammlung zur Geschichte Ermlands, Abt. 1, Bd. 1), Mainz 1860, Nr. 230, s. 386-388. Por. Victor RöHRICH, Die Theilung der Diözese Ermland zwischen dem deutschen Orden und dem ermländischen Bischofe, Zeitschrift für die Geschichte und Altertumskunde Ermlands, Bd. 12: 1897-1899, s. 217-266, tu s. 248-249. W rezultacie tego podziału zakonowi niemieckiemu przypadła cała północna część Barcji, większość części środkowej oraz rejony południowo-wschodnie. Zachodnie i południowo-zachodnie połacie tejże krainy znalazły się we władaniu biskupów warmińskich.

${ }^{11}$ Die Bau- und Kunstdenkmäler der Provinz Ostpreußen (dalej cyt. BKDPOP), H. 2: Natangen, bearb. v. Adolf Boettischer, Königsberg 1898, s. 22-24; Dehio-Handbuch der Kunstdenkmäler West- und Ostpreußen. Die ehemaligen Provinzen West- und Ostpreußen (Deutschordensland Preußen) mit Bütower und Lauenburger Land (dalej cyt. Dehio), bearb. v. Michael Antoni, München-Berlin 1993, s. 40; T. Torbus, Die Konventsburgen, s. 233-236, 350-360; idem, Zamki konwentualne, s. 264-269; Christofer Herrmann, Mittelalterliche Architektur im Preussenland. Untersuchungen zur Frage der Kunstlandschaft und -geographie (Studien zur Internationalen Architektur- und Kunstgeschichte, Bd. 56), Petersberg-Olsztyn 2007, s. 345-346. Ten ostatni badacz uznaje, że prace budowlane podjęte w 1325 r. miały na celu wzniesienie zamku drewnianego, dopiero w 1377 r. zaś, wraz z budową murowanego zamku w Rynie, rozpoczęto prace nad założeniem murowanym. Por. ostatnio: Sławomir JóźwiaK, Janusz TrupindA, Die Bauchronologie und das Raumprogramm der Deutschordensburg Barten (Barciany) im Lichte mittelalterlicher Schriftquellen, Ordines Militares Colloquia Torunensia Historica. Yearbook for the Study of the Military Orders, vol. 23: 2018, s. 301-338, tu s. 307-311. Natomiast Jan Powierski w ogóle podważa tak wczesną chronologię budowy zamku w Barcianach, przesuwając ją na 1340 r. Zob. Jan Powienski, Prusowie, Mazowsze i sprowadzenie Krzyżaków do Polski, t. 2, cz. 1, Malbork 2001, s. 126, 136.

${ }^{12}$ BKDPOP, H. 2, s. 117-118; Dehio, s. 369. Odnośnie do dwufazowych (w latach 19931995 i 2000-2002) badań archeologicznych, geofizycznych i geomorfologicznych na zamku sątoczeńskim por. Jerzy Sikorski, Sątoczno. Geneza i funkcje zamku oraz charakter osady, Warmińsko-Mazurski Biuletyn Konserwatorski, R. 1: 1999, s. 63-83; Aleksander ANDrzeJEwski, Leszek KAJZER, Sprawozdanie $z$ badan archeologiczno-architektonicznych przeprowadzonych na terenie zamku w Satocznie, gm. Korsze, woj. warmińsko-mazurskie w 2001 roku, Łódzkie Sprawozdania Archeologiczne, t. 7: 2001, s. 289-307; iidem, Zamek krzyżacki w Satocznie, gm. Korsze w świetle badań terenowych w 2002 roku, Łódzkie Sprawozdania Archeologiczne, t. 8: 2002-2003, s. 237-251; iidem, Z badań Instytutu Archeologii Uniwersytetu Łódzkiego nad zamkami na terenie województwa warmińsko-mazurskiego, [in:] Pogranicze polsko-pruskie i krzyżackie, red. Kazimierz GrążAwsKi, Włocławek-Brodnica 2003, s. 227-233, tu s. 227-231; iidem, Castle at Sątoczno in "terra Barthensi" or praise of history, [in:] Castella Maris Baltici, Bd. 7: 
części tej krainy podjęto w 1325 r. budowę (rozbudowę?, przebudowę?) zamku w Gierdawach (niem. Gerdauen, ob. ros. Železnodorožnyj) ${ }^{13}$. Sławomir Jóźwiak w 2001 r. uznał, że w połowie lat dwudziestych XIV w. kierownictwo zakonne osiedliło w Gierdawach nowy konwent, a wokół planowało zorganizować okręg komturialny dla północnej części „zakonnej” Barcji ${ }^{14}$. O ile to rozwiązanie nie przetrwało, jak się wydaje, zbyt długo, o tyle nieco bardziej trwały charakter miało powołanie w północnej i w środkowej części Barcji szeregu nowych urzędów niższego stopnia, zwłaszcza prokuratorskich ${ }^{15}$. Za tymi pierwszymi próbami przebudowy zarządu nad zakonną częścią Barcji poszła kolejna, podjęta kilkanaście lat później, kiedy w 1342/1343 r. powołana została do życia komturia leunenburska (sątoczeńska) ${ }^{16}$. Ale i te działania, do drugiej połowy lat czterdziestych XIV w. prowadzone dość intensywnie (w środkowej części „zakonnej” Barcji osadnictwo rozwinęło się głównie w okolicach Leunenburga ${ }^{17}$ ), nie zakończyły się trwałym powodzeniem. Jedną z przyczyn tego stanu rzeczy były bez wątpienia najazdy litewskie w piątej dekadzie tego stulecia i na początku następnej $(1345,1347,1353)$, które doprowadziły omawiane tu tereny do tego stopnia zniszczenia, że konieczna stała się replantacio terre

Beiträge der Tagung „Die Stadt als Burg. Architektur-, rechts- und sozialhistorische Aspekte befestigter Städte im Ostseeraum vom Mittelalter bis zur frühen Neuzeit", 03.-06. September 2003 in Greifswald, hrsg. v. Felix Bierman, Matthias Müller, Christofer Herrmann, Greifswald 2006, s. 9-14; iidem, Zamek w Satocznie w "Terra Barthensi” albo triumf historii, [in:] XIV Sesja Pomorzoznawcza, vol. 2: Od wczesnego średniowiecza do czasów nowożytnych, red. Henryk PANER, Mirosław Fudziński, Gdańsk 2005, s. 197-204; iidem, Sątoczno i Sępopol. Dwa modele rozwoju osadnictwa, [in:] Pogranicze polsko-pruskie i krzyżackie, [t.] 2, red. Kazimierz GrążaWski, Włocławek-Brodnica 2007, s. 275-285, tu s. 276-279; Piotr KitTeL, Rekonstrukcja systemu fos zamku krzyżackiego w Sątocznie, w gminie Korsze, w świetle sondowań geologicznych, Łódzkie Sprawozdania Archeologiczne, t. 8: 2002-2003, s. 253-263.

${ }^{13}$ BKDPOP, H. 2, s. 98-99; Dehio, s. 202-203. Nie sposób przy obecnym stanie badań tego obiektu rozstrzygnąć, czy (tudzież w jakim stopniu) była to budowla murowana, i o jakiej morfologii. Karl H. Clasen skłonny był łączyć rozbudowę (lecz nie budowę) murowanego zamku ze wznoszeniem murów miejskich poświadczonym źródłowo w 1406 r. Zob. Karl H. Clasen, Die mittelalterliche Kunst im Gebiete des Deutschordensstaates Preußen, Bd. 1: Die Burgbauten, Königsberg i. Pr. 1927, s. 142.

${ }^{14}$ Sławomir JóźwIAK, Centralne i terytorialne organy władzy zakonu krzyżackiego w Prusach w latach 1228-1410. Rozwój - przekształcenia - kompetencje, Toruń 2012, s. 125-127.

${ }^{15}$ Por. w tej kwestii szerzej: idem, Przeksztatcenia administracyjne na poludniowo-wschodnich rubieżach państwa krzyżackiego w latach czterdziestych XIV wieku, Komunikaty Mazursko-Warmińskie, 1999, nr 1 (223), s. 3-14, tu s. 3-4; idem, Centralne i terytorialne organy władzy, s. 127, przyp. 284.

${ }^{16}$ Idem, Przekształcenia administracyjne, s. 4-9; idem, Centralne i terytorialne organy władzy, s. 129-130.

${ }^{17}$ K. KAsIsKe, op.cit., s. 101, 105-106. Jednym z elementów akcji osadniczej było nadawanie licznych przywilejów dla bałtyjskich „wolnych” w rejonie Leunenburga na przełomie lat trzydziestych i czterdziestych XIV w., które na tym obszarze poprzedzało z reguły lokowanie pierwszych wsi czynszowych. 
Barthen ${ }^{18}$. Rola zamku Rastenburg, który według wczesnonowożytnej tradycji narracyjnej miał zostać założony w $1329 \mathrm{r}^{19}$, a więc na początku kolonizowania przez Zakon środkowej części Barcji, jawi się w tym pierwszym etapie zagospodarowywania rejonu dość niejasno ${ }^{20}$, przy czym dopiero w $1342 \mathrm{r}$., a zatem w drugim okresie kolonizacji obszarów barciańskich, potwierdzony jest tam zarządca określany mianem „prokuratora” ${ }^{21}$. Następny (trzeci) okres intensywnej aktywności osadniczej w środkowej części „zakonnej” Barcji datowany jest na lata sześćdziesiąte i siedemdziesiąte XIV w., kiedy działaniami osiedleńczymi - w wielu okolicach podejmowanymi wówczas na nowo - objęte zostały również rejony Rastenburga i Bartenburga ${ }^{22}$. Wydaje się, że najpóźniej w tym czasie zamek rastenburski musiał zostać dostosowany do spełniania istotnej w kontekście osłony osadników funkcji refugialnej ${ }^{23}$.

${ }^{18}$ Preußisches Urkundenbuch. Politische (allgemeine) Abteilung (dalej cyt. PUB), Bd. 4: 1346-1351, hrsg. v. Hans Koeppen, Marburg 1960, Nr. 365, s. 333-334, tu s. 334 (= Codex diplomaticus Prussicus. Urkunden-Sammlung zur ältern Geschichte Preussens aus dem Königl. Geheimen Archiv zu Königsberg nebst Regesten [dalej cyt. CDP], Bd. 3, hrsg. v. Johannes VoIGT, Königsberg 1848, Nr. 57, s. 79-80). W kwestii zniszczeń obszarów barciańskich w rezultacie najazdów litewskich por. S. Jóźwiak, Przekształcenia administracyjne, s. 10, 12. W przypisach do niniejszego tekstu wprowadzono dwa dodatkowe skróty: tylda ( ) oznacza inną wersję tego samego przekazu źródłowego, a znak równości (=) - tożsamą wersję.

${ }^{19}$ Christoph M. Hartinoch, Alt- und Neues Preussen oder Preussischer Historien, Franckfurt-Leipzig 1684, s. 422; za nim K. KAsıSKE, op.cit., s. 101. Datację taką odrzucił J. PowiERSKI, op.cit., s. 138. Opowiedział się on za chronologią budowy zamku w 1341/1342 r.

${ }^{20}$ Jerzy Sikorski widzi w drewniano-ziemnym zamku rastenburskim „strażnicę” osłaniającą tereny zakonne przed nieprzyjaznymi akcjami Litwinów, w dodatku dopatrując się w grupie kilku podobnych punktów umocnionych systemowego charakteru, w ramach którego „strażnice, niezależnie od ich roli indywidualnej w odpowiednich rejonach osadniczych i okręgach administracyjnych, pozostawały we wzajemnym związku, jako ogniwa przemyślanej strategii w zakresie obrony północno-wschodnich rubieży kraju”. Autor jednak w ogóle nie podnosi kwestii ewentualnych związków budowy tego zamku z zagospodarowywaniem okolicznych obszarów. Zob. Jerzy Siкorsкi, Kętrzyn średniowieczny, [in:] Kętrzyn. Dzieje miasta, red. Stanisław Aснremczyк, Kętrzyn-Olsztyn 2016, s. 85-152, tu s. 90.

${ }^{21}$ S. Jóźwiak, Przekształcenia administracyjne, s. 4.

${ }^{22}$ K. Kasiske, op.cit., s. 107-109.

${ }^{23}$ Nie można wykluczyć, że początkowo zamek przedstawiał rodzaj wildhausu i tak był traktowany przez kierownictwo zakonu niemieckiego (o tej późnośredniowiecznej funkcjonalnej kategorii klasyfikacyjnej zob. K. Kwiatкowski, (Wild)haus w Bezławkach, s. 36-37), by po pewnym czasie, najpóźniej ok. 1356 r. (por. Carl BeckHerrn, Verzeichniss der die Stadt Rastenburg betreffenden Urkunden, Altpreußische Monatsschrift, Bd. 22: 1885, s. 505-605, edycja na s. 506-578, tu s. 506), zostać przekształconym funkcjonalnie na siedzibę prokuratora, a wreszcie - prawdopodobnie około siódmej-dziewiątej dekady XIV w. - otrzymać nową morfologiczną postać prostokątnego, trójskrzydłowego założenia. Już Carl Beckherrn zauważył, że pewne cechy architektoniczne zamku pozwalają przypuszczać, iż nie od razu powstał on jako założenie obronne w obecnie zachowanym kształcie. Zob. Carl BeckHERrn, Das Ordenshaus Bäslack, Altpreußische Monatsschrift, Bd. 21: 1884, s. 637-649, tu s. 640, przyp. 9. Obserwacje Tomasza Torbusa $\mathrm{z}$ lat dziewięćdziesiątych ubiegłego wieku szły w kierunku podkreślenia daleko idących 
Biorąc pod uwagę fakt, że położona niespełna $10 \mathrm{~km}$ (w linii powietrznej) na południowy zachód od Rastenburga warownia w Bezławkach wykazuje morfologicznie wyraźne dostosowanie całego założenia obronnego dla potrzeb pomieszczenia znacznej liczby osób, na co zwracali już uwagę autorzy gdańskiej monografii z 2013 r., słusznie idąc w kierunku interpretacji o funkcji refugialnej jako jednej z głównych, które wyznaczono nowo wznoszonemu zamkowi ${ }^{24}$, wypada postawić pytanie o związek budowy warowni z działaniami

podobieństw architektoniczno-stylistycznych do zamków w Insterburgu (stpol. Wystruć, ob. ros. Černâchovsk) oraz Ortelsburgu (ob. pol. Szczytno), i dopatrywania się we wszystkich trzech obiektach prac tego samego warsztatu budowlanego. Por. T. Torbus, Die Konventsburgen, s. 229-230; idem, Zamki konwentualne, s. 260, 262. Odrzucając przyjętą przez gdańskiego historyka sztuki (por. T. ToRbus, Die Konventsburgen, s. 228; idem, Zamki konwentualne, s. 259) datę 1377 r. jako moment podjęcia budowy rzekomego „nowego zamku” w Insterburgu, wynika ona bowiem $\mathrm{z}$ bezkrytycznego potraktowania nowoniemieckiego tekstu kroniki Stenzela (Stanisława) Bornbacha, który niewłaściwie zrozumiał przekaz kroniki Wiganda von Marburg i określenie neu hausz odniósł do Insterburga, a nie do "nowego zamku” w ziemi trockiej (tj. być może do Nowych Trok) (por. Die Chronik Wigands von Marburg. Originalfragmente, lateinische Übersetzung und sonstige Überreste, hrsg. v. Theodor Hirsch, [in:] Scriptores rerum Prussicarum, Bd. 2, hrsg. v. Theodor Hirsch, Max Töppen, Ernst StreHLKe, Leipzig 1863, s. 429-662, edycja na s. 453-662 [dalej cyt. Wigand], tu cap. 97, s. 587 [na tej stronie także wydrukowany fragment dzieła S. Bornbacha]), jak również niejednoznaczną narrację wspomnianej kroniki Wigana von Marburg o ewentualnym zniszczeniu w 1370 r. zamku ortelsburskiego przez wojsko Kiejstuta (por. Wigand, cap. 76, s. 568; BKDPOP, H. 3: Das Oberland, hrsg. v. Adolf BoETTISCHER, Königsberg 1893, s. 99; podobnie Dehio, s. 456; za tymi katalogami również: T. ToRBus, Die Konventsburgen, s. 230; idem, Zamki konwentualne, s. 263; Ch. Herrmann, Mittelalterliche Architektur im Preussenland, s. 631), ale akceptując wstępnie wskazane przez T. Torbusa chronologiczne wskaźniki stylistyki architektonicznej (por. T. Torbus, Die Konventsburgen, s. 231-232; idem, Zamki konwentualne, s. 263), można by ostrożnie zakładać, że trójskrzydłowy zamek rastenburski wzniesiono między ok. 1370 a ok. 1390 r., co nie oznacza bynajmniej, że mury bądź wały obwodowe wokół rozszerzonego placu zamkowego nie mogły zostać wzniesione wcześniej. Wobec braku przesłanek opartych na badaniach archeologicznych kwestia ta musi pozostać na razie nierozstrzygnięta. Ostatnio Ch. Herrmann opierając się na opinii wyrażonej w nowo opracowanym „pruskim” tomie Stownika zabytków sztuki Georga Dehio, datuje rozbudowę/przebudowę zamku na siódmą dekadę XIV w. Zob. Ch. Herrmann, Mittelalterliche Architektur im Preussenland, s. 668. Podobnie nieco wcześniej (za starszą literaturą, m.in. K. H. Clasenem) uczynił to Jan Salm. Zob. Jan Salm, Kętrzyn, [in:] Leszek Kajzer, Stanisław KoŁodziejSKi, Jan SAlm, Leksykon zamków w Polsce, red. Leszek Kajzer, Warszawa 2001, s. 223-225, tu s. 223.

${ }^{24}$ Wojciech WóŁKowski, Architektura zamku w Bezławkach, [in:] Bezławki - ocalić od zniszczenia. Wyniki prac interdyscyplinarnych prowadzonych w latach 2008-2011, red. Arkadiusz Koperkiewicz (Gdańskie Studia Archeologiczne, nr 3), Gdańsk 2013, s. 109-117, tu s. 111; Wojciech Brillowski, Analiza funkcjonalna założenia obronnego w Bezławkach, [in:] ibid., s. 119-135, tu s. 131; Wojciech Brillowski, Arkadiusz Koperkiewicz, Archaeological and Art History Research in Bezławki: Analysis of Form and Function of Small Castle Architecture in the Eastern Part of Teutonic Order's Lands, [in:] Castella Maris Baltici, [vol.] 10: Finland 24-29.8.2009. Raseborg, Olavinlinna and Häme Castles, ed. Kari Uotila, Terhi Miккоla, Anna-Maria Vilkuna (Archaeologia Medii Aevi Finlandiae, vol. 18), Saarijärven 2012, s. 33-43, 
kolonizacyjnymi $\mathrm{w}$ okolicy $\mathrm{w}$ tym właśnie trzecim okresie akcji osadniczej $\mathrm{w}$ „zakonnej” Barcji. Należy w tym miejscu przypomnieć, że oparta na badaniach dendrochronologicznych z 2009 r. datacja budowy założenia bezławeckiego nie jest bynajmniej ścisła. Wbrew dość arbitralnym opiniom autorów wspomnianej monografii z $2013 \mathrm{r}^{25}$ trudno wyłącznie na bazie wykonanych analiz dendrochronologicznych jednoznacznie wnioskować co do tego, kiedy rozpoczęto prace przy wnoszeniu warowni i kiedy je ukończono. Obydwa uzyskane średniowieczne datowania pozyskanych próbek drewna wykazują znaczną rozpiętość $\left(1367^{+x} /{ }_{-6}\right.$ oraz $\left.1377^{+8} /{ }_{-6}\right)$, mieszcząc się łącznie w przedziale niemal ćwierćwiecza $(1361-[1385])^{26}$.

Bliższa analiza chronologii aktywności osadniczej prowadzonej przez zakon niemiecki w rejonie dolnej i środkowej Dajny (na obszarach barckich rozciągających się na południe i zachód od Rastenburga) pozwala na zdobycie konkretnych przesłanek umożliwiających pewne uściślenie zakresu czasowego, w jakim podjęto budowę zamku w Bezławkach. W świetle zachowanych przekazów pisanych, którymi są oryginały bądź (częściej) odpisy dokumentów nadawczych wystawianych przez braci-urzędników zakonu niemieckiego dla lokatorów wsi oraz odbiorców prywatnych, głównie posiadaczy ziemskich - tzw. wolnych (freien), do roku 1370 działania kolonizacyjne w okolicach środkowego i dolnego biegu Dajny, nad którym zlokalizowane było ówczesne pole (lauks) Bayslaugken ${ }^{27}$, znajdowały się w fazie wstępnej. Na terenach między Rastenburgiem a Szestnem ograniczały się one zaledwie do najprawdopodobniej łącznie 11 nadań uczynionych w latach 1364 (las Krakentin) ${ }^{28}, 1367$

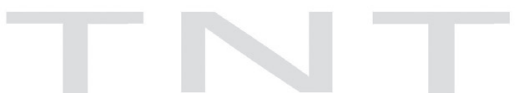

tu s. 39; wcześniej również T. ToRbus, Zamki krzyżackie, s. 31; por. także moje rozważania w tej kwestii: K. Kwiatкоwsкi, (Wild)haus w Bezławkach, s. 11-14, 16.

${ }^{25}$ Tomasz WAżNy, Analiza dendrochronologiczna drewna z zamku w Bezławkach (woj. warmińsko-mazurskie), [in:] Bezławki - ocalić od zniszczenia. Wyniki prac interdyscyplinarnych prowadzonych w latach 2008-2011, red. Arkadiusz Koperkiewicz (Gdańskie Studia Archeologiczne, nr 3), Gdańsk 2013, s. 272-273; za nim dość arbitralnie S. SzCzePAŃsKI, op.cit., s. 28; W. WóŁKOWSKI, op.cit., s. 109, przyp. 2; W. BrIllowsKI, op.cit., s. 132; por. także W. BrillowSKI, A. KoperkieWICZ, op.cit., s. 41.

${ }^{26}$ T. WAŻNY, op.cit., s. 273.

${ }^{27}$ Por. S. Szczepański, op.cit., s. 23-24; Krzysztof Kwiatкowski, Bezławki - kilka uzupetnień źródłowych dotyczących późnośredniowiecznego zespołu osadniczego na obrzeżach kraju pruskiego, Komunikaty Mazursko-Warmińskie, 2016, nr 1 (291), s. 31-53, tu s. 32-36.

${ }^{28}$ Nadanie 20 łanów w lesie Krakentin (niem. wieś Krakotin, ob. pol. Krakocin, ok. 6 km NW od Bezławek) na prawie chełmińskim, z obowiązkiem służby zbrojnej, uczynione [30 X] $1364 \mathrm{r}$. Por. GStA PK, XX. HA, Etats-Ministerium (dalej cyt. EM) 119d, Nr. 5, k. 5r-5v (68r-68v) (= regest: PUB, Bd. 6, Lief. 1: 1362-1366, hrsg. v. Klaus Conrad, Marburg 1986, Nr. 318, s. 179 [z błędną sygnaturą archiwalną]). 
(pole Raunewange) $^{29}$ i w 1369 (okolica [pole?] Bose) ${ }^{30}$, do których zapewne

${ }^{29}$ W dniu 24 V 1367 r. na polu Raunewange (późniejsza wieś Rudwangen, ob. pol. Rydwągi, położone $5 \mathrm{~km}$ SSE od Bezławek) nadane zostały trzy majątki ziemskie (każdy po 11 łanów) dla trzech posiadaczy na prawie chełmińskim, zobowiązanych do służby zbrojnej (z wolnizną w wysokości 15 lat). Por. 1. - GStA PK, XX. HA, Ostpreußische Folianten (dalej cyt. Ostpr. Fol.) 124, fol. 277r-277v ( GStA PK, XX. HA, Ostpr. Fol. 126, fol. 10r-10v = regest: PUB, Bd. 6, Lief. 2: 1367-1371, hrsg. v. Klaus Conrad, Marburg 2000, Nr. 549, s. 308-309); 2. - GStA PK, XX. HA, Ostpr. Fol. 124, fol. 277v-278v ( GStA PK, XX. HA, Ostpr. Fol. 126, fol. 9v-10r = regest: PUB, Bd. 6, Lief. 2, Nr. 550, s. 309); 3. - GStA PK, XX. HA, Ostpr. Fol. 124, fol. 278v ( GStA PK, XX. HA, Ostpr. Fol. 126, fol. 9r-9v = regest: PUB, Bd. 6, Lief. 2, Nr. 551, s. 309). Por. też Paul GLass, Unsere Heimat zur Zeit des Deutschen Ordens, [in:] Der Kreis Sensburg, hrsg. v. Fritz BredenBERG (Ostdeutsche Beiträge aus dem Göttinger Arbeitskreis, Bd. 15), Würzburg 1960, s. 59-78, tu s. 67; Fritz Stomber, Die erste Besiedlung des Kreises Sensburg, [in:] Unsere masurische Heimat. Zum hundertjährigen Bestehen des Kreises Sensburg, hrsg. v. Karl Templin, Sensburg 1926, s. 122-133, tu s. 123; K. Kasiske, op.cit., s. 123; Max Toeppen, Historia Mazur. Przyczynek do dziejów krainy i kultury pruskiej, tł. Małgorzata Szymańska-JAsı́́ska, Olsztyn 1995, s. 116; Wojciech KętrzyŃski, O ludności polskiej w Prusiech niegdyś krzyżackich, wstęp i red. Grzegorz BIAŁuński (Rozprawy i Materiały Ośrodka Badań Naukowych im. Wojciecha Kętrzyńskiego w Olsztynie, nr 240), Olsztyn 2009, s. 338. W 1373 r. doszło do tego kolejne nadanie wielkości 10 łanów na prawie chełmińskim z obowiązkiem służby zbrojnej, ale już bez wolnizny. Por. GStA PK, XX. HA, Ostpr. Fol. 124, fol. 89r. Lidia Wakuluk idąc za wzmianką Karla Kasiskego (K. KASISKE, op.cit., s. 108), błędnie uznała rok 1373 za moment przeprowadzenia tu akcji kolonizacyjnej, dodatkowo myląc nadanie dóbr ziemskich z lokacją wsi na prawie chełmińskim. Zob. Lidia WAKULUK, Osadnictwo i sieć parafialna kętrzyńskiego okręu prokuratorskiego w XIV-XV wieku, Komunikaty Mazursko-Warmińskie, 1976, nr 3 (133), s. 375-394, tu s. 385.

${ }^{30} \mathrm{~W}$ dniu 6 VII 1369 r. w okolicy nazywanej Boze (bałtyjski lauks [?], późniejsze niem. wsie Bosemb, ob. pol. Boże, 9,5 km SE od Bezławek oraz Wilkendorf, ob. pol. Wilkowo, 2 km EES od Bezławek) nadanych zostało najprawdopodobniej siedem majątków ziemskich, każdy o powierzchni 12 łanów, na prawie chełmińskim, z obowiązkiem jednej służby zbrojnej z majątku, lecz zarazem z 15 latami wolnizny od tej powinności - łącznie dobra te liczyły 84 łany. Por. 1. - GStA PK, XX. HA, Pergamenturkunden (dalej cyt. Perg.-Urk.), Schiebl. XXXIX, Nr. 51 (= regest: PUB, Bd. 6, Lief. 2, Nr. 740, s. 421-422); 2. - GStA PK, XX. HA, Ostpr. Fol. 322, fol. 360r-360v ( GStA PK, XX. HA, Ostpr. Fol. 447, fol. 431r-431v = regest: PUB, Bd. 6, Lief. 2, Nr. 741, s. 423); 3.-4. - GStA PK, XX. HA, Ostpr. Fol. 322, fol. 361r-361v, 363r-363v ( GStA PK, XX. HA, Ostpr. Fol. 447, fol. 428v-429r = regest: PUB, Bd. 6, Lief. 2, Nr. 742, s. 423); 5. - GStA PK, XX. HA, Ostpr. Fol. 124, fol. 11r-11v ( GStA PK, XX. HA, Ostpr. Fol. 322, fol. 364r-363v GStA PK, XX. HA, Ostpr. Fol. 447, fol. 430r-430v = regest: PUB, Bd. 6, Lief. 2, Nr. 743, s. 423); 6.-7. - GStA PK, XX. HA, Ostpr. Fol. 322, fol. 362r-362v, 365r-364v ( GStA PK, XX. HA, Ostpr. Fol. 447, fol. 429r-430r, 431v-432v = regest: PUB, Bd. 6, Lief. 2, Nr. 744, s. 424). Por. też K. KAsIsKe, op.cit., s. 108, 122. Słusznie Klaus Conrad wskazał (por. PUB, Bd. 6 , Lief. 2, s. 422), że literalne powtórzenie w Ostpr. Fol. 322 treści dwóch dokumentów miało służyć stworzeniu podstawy prawnej dla faktycznych szesnastowiecznych posiadaczy ziemskich, w sytuacji, gdy pierwotnych nadań dla dwóch majątków nie udało się wówczas odnaleźć. L. Wakuluk idąc za K. Kasiskem, błędnie przyjęła nadanie w okolicach późniejszego Wilkowa tylko pięciu służb zbrojnych, nieprawidłowo również uznając owe majątki za wieś czynszową na prawie chełmińskim, dodatkowo jeszcze w przypisie (nr 192) przytaczając błędny odnośnik źródłowy. Zob. L. WAKULUK, op.cit., s. 388; K. KASISKe, op.cit., s. 108. Z kolei S. Szczepański również za K. Kasiskem podał błędną datę nadania majątków w okolicach późniejszego Wilkowa - rok 
należy doliczyć jeszcze jedno dające się tylko ogólnie datować na okres przed 18 XII $1371 \mathrm{r}^{31}$ Nie ma przy tym pewności, czy zachowany materiał źródłowy stanowi adekwatne poświadczenie ówczesnych działań władczo-osadniczych Zakonu w tym rejonie. Dalej zachowane źródła wskazują na to, że począwszy od roku 1370, w ciągu kolejnej dekady nastąpiła w tym rejonie zauważalna intensyfikacja akcji kolonizacyjnej. W tymże $1370 \mathrm{r}$. poświadczone jest jedno pewne $^{32}$ nadanie (las Cracotin/Crakentin) ${ }^{33}$, w 1371 r. trzy (an der Rußkayn ${ }^{34}$,

1396 - podczas gdy jest to błąd drukarski w tekście pruskiego historyka (powinna być właściwa data 1369 r.). Zob. S. SzCZEPAŃsKi, op.cit., s. 25.

${ }^{31}$ Chodzi o dobra wielkości 20 łanów położone w Gudenicken (niem. Gudnick, ob. pol. Gudniki, 13 km NW od Bezławek), które Andirke (Andreas) Sparwin (Sparwein) kupił od swojego krewnego Hannike Sperwiena (Sparweina) w czasach urzędowania komtura bałgijskiego Ulricha Frickego, tj. między 5 IV 1360 a 18 XII 1371 r., o czym wiadomo z dokumentu z 22 XII 1375 r. Por. GStA PK, XX. HA, Ostpr. Fol. 124, fol. 69r-69v (= edycja z innej podstawy źródłowej: Adolf Rogge, Das älteste Urkunde über die Familie Sparwin vom 22. Decbr. 1375, AltpreuBische Monatsschrift, Bd. 12: 1875, s. 377-378= regest: PUB, Bd. 6, Lief. 2, Nr. 1004, s. 575). To z kolei oznacza, że Andirke Sparwein musiał wejść w posiadanie owego majątku jakiś czas przed 18 XII 1371 r., zapewne jeszcze w latach sześćdziesiątych XIV stulecia. Dokument wyroku arbitrażowego w konflikcie warmińsko-zakonnym wydanego 28 VII 1374 r. wspomina osadę (zapewne majątek) Sogatytin należącą do tejże rodziny Sparwein (Sparwin), którą z kontekstu opisu granicy warmińsko-zakonnej należy lokalizować nieopodal Gudników, tym bardziej że była ona położona naprzeciwko warmińskiej wsi Tolnykendorff (późn. niem. Tolnigk, ob. pol. Tolniki Małe). Por. CDW, Bd. 2: Urkunden der Jahre 1341-1375 nebst Nachträgen von 1240-1340, hrsg. v. Carl P. WoelKY, Johann M. SAAGE (Monumenta Historiae Warmiensis oder Quellensammlung zur Geschichte Ermlands, Abt. 1, Bd. 2), Mainz 1864, Nr. 497, s. 518-533, tu s. 527. Ten sam dokument (por. CDW, Bd. 2, Nr. 497, s. 527-528) wskazuje również na istnienie w tym czasie w tej okolicy osady Sparwynen, która była zapewne główną siedzibą rodziny.

${ }^{32}$ Nie udało się źródłowo zweryfikować obecnej w literaturze wzmianki dotyczącej nadania Winricha von Kniprode dla prawdopodobnie ośmiu osób („Michel und Marten Niclas Hans Matz Heinrich Andreas und Weinrich Reimann"), które w 1370 r. otrzymały dobra w Bussen (późniejsza niem. wieś Bosemb, ob. pol. Boże). Por. F. Stomber, Die erste Besiedlung, s. 124; P. Glass, op.cit., s. 68; Gustaw Leyding, Dzieje wsi, [in:] Mragowo. Z dziejów miasta i powia$t u$, red. Andrzej WAKAR, Olsztyn 1975, s. 137-216, tu s. 143 (tu wzmianka o „ośmiu braciach”); W. KęTRZYŃski, op.cit., s. 338 (również podał imiona ośmiu członków rodziny "Reiman”, a wielkość nadanych dóbr określił łącznie na 57 łanów).

${ }^{33}$ Nadanie 20 łanów i 20 morgów w lesie Cracotin/Crakentin (niem. wieś Krakotin, ob. pol. Krakocin, ok. 6 km NW od Bezławek) uczynione 2 XII 1370 r. dla tego samego odbiorcy (Pezsche Rosenburger/Rezenburger), co w 1364 r. (por. przyp. 28). Por. GStA PK, XX. HA, Ostpr. Fol. 124, fol. 105v-106r (= regest: PUB, Bd. 6, Lief. 2, Nr. 866, s. 503-504); por. też K. KasisKe, op.cit., s. 106.

${ }^{34}$ Nadanie 10 łanów an der Rußkayn (późniejsza niem. wieś Langenbrück, ob. pol. Lembruk, $7 \mathrm{~km}$ na SSW od Bezławek) na prawie chełmińskim z obowiązkiem służby zbrojnej, uczynione 22 IV 1371 r. Por. GStA PK, XX. HA, Ostpr. Fol. 124, fol. 279v-280r (= regest: PUB, Bd. 6, Lief. 2, Nr. 902, s. 524); por. też F. STOMBer, Die erste Besiedlung, s. 123; K. KAsiske, op.cit., s. 122; W. KęTRZYŃsKI, op.cit., s. 338 (z błędną datacją na 1370 r.). 
Bayselauken $^{35}$, Wenedeyn ${ }^{36}$ ), w 1372 r. jedno (Schoneflysse) ${ }^{37}$, w 1373 r. jedno $\left(\right.$ Weissenen $\left.^{38}\right)$, w 1374 r. dwa $\left(\right.$ Schenwiesen $^{39}$, Tolkesdorf ${ }^{40}$ ), następnie w 1376 r. sześć (bądź siedem) (Weissenburgk ${ }^{41}$, Ruszken ${ }^{42}$ ), w 1377 r. jedno

${ }^{35}$ Dokument lokacyjny wsi czynszowej Bayselauken (niem. Bäslack, ob. pol. Bezławki) na prawie chełmińskim o powierzchni 44 łanów, wystawiony 9 VIII 1371 r. Por. GStA PK, XX. HA, Ostpr. Fol. 124, fol. 17v-18v (= regest: PUB, Bd. 6, Lief. 2, Nr. 926, s. 538); por. też S. SzczepańSKI, op.cit., s. 24; wcześniej także L. WAKULUK, op.cit., s. 377; K. KASISKE, op.cit., s. 108.

${ }^{36}$ Nadanie pięciu łanów w Wenedeyn (niem. Wendehnen, ob. pol. Wandajny, $16 \mathrm{~km} \mathrm{NW}$ od Bezławek) na prawie pruskim z obowiązkiem służby zbrojnej, uczynione 5 VII $1371 \mathrm{r}$. Por. GStA PK, XX. HA, EM 13a I, Nr. 120, s. 15 (= regest: PUB, Bd. 6, Lief. 2, Nr. 919, s. 534).

${ }^{37}$ Dokument lokacyjny wsi czynszowej Schoneflysse (niem. Schönfliess, ob. pol. Kraskowo, $14 \mathrm{~km} \mathrm{NW}$ od Bezławek) na prawie chełmińskim o powierzchni 65 łanów, wystawiony 2 II 1372 r. Por. GStA PK, XX. HA, Ostpr. Fol. 124, fol. 21v-22v ( GStA PK, XX. HA, Ostpr. Fol. 322, fol. 387v-389r); por. też L. WAKULUK, op.cit., s. 380; K. KASISKE, op.cit., s. 106.

${ }^{38}$ Nadanie łącznie 120 łanów w Weissenen/Weystennen (późniejsze niem. wsie: Sonntag, ob. pol. Zyndaki, 13 km SSW od Bezławek; Warpuhnen, ob. pol. Warpuny, $12 \mathrm{~km}$ SSW od Bezławek; Schellongowken [od 1938 r. Schillingshöfen], ob. pol. Szelągówka, 15,5 km SSW od Bezławek) na prawie chełmińskim z obowiązkiem świadczenia czterech służb zbrojnych, uczynione 10 VII 1373 r. Por. GStA PK, XX. HA, Ostpr. Fol. 126, fol, 32r (= edycja z innej podstawy źródłowej: F. SтомвеR, Die erste Besiedlung, s. 126); por. też P. Glass, op.cit., s. 68-69; G. LeYDing, op.cit., s. 194; F. Stomber, Die erste Besiedlung, s. 124; M. Toeppen, Historia Mazur, s. 117; W. KęTRZYŃsKI, op.cit., s. 338; [s.n.] MüHLING, Statistische und andere Notizen aus einer alten Amtsrechnung aus Sehisten, Neue Preußische Provinzial-Blätter. Andere Folge, Bd. 3: 1853, s. $220-229,259-270$, tu s. $263-264$.

${ }^{39}$ Dokument lokacyjny wsi czynszowej Schenwiesen (późniejsza niem. wieś Laxdoien, ob. pol. Łazdoje, $2 \mathrm{~km}$ SE od Bezławek) na prawie chełmińskim o powierzchni 30 łanów, wystawiony 26 I 1374 r. Por. GStA PK, XX. HA, Ostpr. Fol. 322, fol. 463r-464r; por. S. SzCZEPAŃsKi, op.cit., s. 24-25; L. WAKULUK, op.cit., s. 382; K. KASISKE, op.cit., s. 108.

${ }^{40}$ Dokument lokacyjny wsi czynszowej Tolkesdorf (niem. Tolkendorf, ob. pol. Tołkiny, $11 \mathrm{~km}$ NNW od Bezławek) na prawie chełmińskim o powierzchni 32,5 łana, wystawiony 10 II 1374 r. Por. GStA PK, XX. HA, Ordensbriefarchiv (dalej cyt. OBA) 363, s. 1-3.

${ }^{41} \mathrm{~W}$ dniu 1 I $1376 \mathrm{r}$. w miejscu zwanym Weissenburgk (niem. Weissenburg, ob. pol. Wyszembork, $11 \mathrm{~km}$ SE od Bezławek) nadanych zostało pięć lub nawet sześć majątków ziemskich o powierzchni 10 łanów każdy, na prawie chełmińskim, z obowiązkiem służby zbrojnej z każdego nadania. Por. 1. - GStA PK, XX. HA, Ostpr. Fol. 124, fol. 281r-281v ( GStA PK, XX. HA, Ostpr. Fol. 126, fol. 4v-5r); 2.-3. - GStA PK, XX. HA, Ostpr. Fol. 124, fol. 284r-284v, 284v-285r ( GStA PK, XX. HA, Ostpr. Fol. 126, fol. 5r-6r); 4. - GStA PK, XX. HA, Ostpr. Fol. 124, fol. 285v-286r; 5. - GStA PK, XX. HA, Ostpr. Fol. 124, fol. 286r-286v; 6. - GStA PK, XX. HA, Ostpr. Fol. 126, fol. 6r-6v. Por. też P. GLAss, op.cit., s. 68; G. LeYding, op.cit., s. 204 (błędnie wymienia tylko cztery majątki); F. STOMBER, Die erste Besiedlung, s. 123; K. KAsiske, op.cit., s. 122 (błędnie podaje 1373 r. jako datę); M. Toeppen, Historia Mazur, s. 116-117 (również pisze błędnie o tylko czterech nadaniach); W. KęTRzyŃski, op.cit., s. 339 (wymienił łącznie siedem przywilejów, ale z lat 1376, 1377 i 1388, co oznacza, iż uznał, że nadań z 1 I 1376 r. było pięć).

${ }^{42}$ Nadanie ośmiu łanów bey der bencke zw Ruszken (późniejsza niem. wieś Reuschendorf, ob. pol. Ruska Wieś, 8,5 km na SSE od Bezławek) na prawie chełmińskim z obowiązkiem służby zbrojnej. Por. GStA PK, XX. HA, Ostpr. Fol. 126, fol. 10v-11r; por. też M. ToEPPEN, Historia Mazur, s. 117 (błędnie podaje liczbę 10 łanów); W. KęTRZYŃsKI, op.cit., s. 339. 
(Weissenburgk) ${ }^{43}, 1378$ r. jedno (Weddern $)^{44}$ oraz jeszcze jedno nadanie uczynione w okresie 1374/1375-1382 (Pilcze) $)^{45}$. W odniesieniu do jednej osady wzmiankowanej w $1374 \mathrm{r}^{46}$ nie można zweryfikować chronologii jej powstania. Łącznie dostępny materiał źródłowy dla okresu 1370-1378 [1382] dokumentuje 16 lub 17 (a może nawet $20^{47}$ ) nadań, co w porównaniu do 11 lub 12 nadaniami z lat [ok. 1360] 1364-1369 nie stanowi jakiegoś nadzwyczajnego przyrostu kwantytatywnego, ale już pod względem kwalitatywnym wskazuje na istotną zmianę. O ile wszystkie 11 lub 12 nadań odnotowanych przed $1370 \mathrm{r}$. stanowiły donacje uczynione na rzecz posiadaczy ziemskich (wolnych), o tyle w kolejnej fazie bracia zakonu niemieckiego podjęli w rejonie środkowego i dolnego biegu Dajny akcję lokacji pięciu wsi czynszowych na prawie chełmińskim. Co istotne, po $1378 \mathrm{r}$. przez następnych siedem lat aż do $1386 \mathrm{r}^{48}$ nie ma poświadczonych kolejnych nadań na analizowanym obszarze ${ }^{49}$. W rezultacie w opartym na danych dendrochronologicznych około 25-letnim hory-

${ }^{43}$ Nadanie 10 łanów w Weissenburgk (niem. Weissenburg, ob. pol. Wyszembork) na prawie chełmińskim z obowiązkiem służby zbrojnej (niedatowane dziennie). Por. GStA PK, XX. HA, Ostpr. Fol. 126, fol. 4r-4v; por. G. LeYdinG, op.cit., s. 204; W. KĘTRZYŃsKi, op.cit., s. 339.

${ }^{44}$ Nadanie 10 łanów na polu Weddern (późniejsza niem. wieś Widrinnen, ob. pol. Widryny, 8 km na SW od Bezławek) na prawie chełmińskim z obowiązkiem służby zbrojnej, uczynione 6 V 1378 r. Por. GStA PK, XX. HA, Ostpr. Fol. 126, fol. 20r-21r; por. też K. KASISKE, op.cit., s. 122; M. Toeppen, Historia Mazur, s. 117; W. KęTRZYŃski, op.cit,, s. 339.

${ }^{45}$ Dokument lokacyjny wsi czynszowej Pilcze (niem. Pülz, ob. pol. Pilec, 4,5 km SSW od Bezławek) na prawie chełmińskim o powierzchni 46 łanów, wystawiony 8 II 1383 r. i potwierdzający lokację tejże wsi przez komtura bałgijskiego Dietricha von Elner ([po 22 XI] 1374 19 IX 1382). Por. GStA PK, XX. HA, Perg.-Urk., Schiebl. XXVII, Nr. 190 (= regest: Regesta historico-diplomatica Ordinis S. Mariae Theutonicorum 1198-1525, pars 2: Regesta Privilegiorum Ordinis S. Mariae Theutonicorum, bearb. v. Erich Јоаснім [et al.], hrsg. v. Walther Нubatsch, Göttingen 1948, Nr. 1096, s. 131-132); por. też K. KAsIsKE, op.cit., s. 122 (sytuujący lokację w okresie 1374-1382); wcześniej także M. Toeppen, Historia Mazur, s. 115; W. KęTRZYŃski, op.cit., s. 340.

${ }^{46}$ Chodzi o osadę (wieś?) Babaczin/Babezcin (niem. Babziens, ob. pol. Babieniec, 10,5 km NW od Bezławek), wzmiankowaną w dokumencie wyroku arbitrażowego z 28 VII 1374 r. Por. CDW, Bd. 2, Nr. 497, s. 527-528.

${ }^{47}$ Por. przyp. 32, 45 i 46.

${ }^{48}$ Archiwum Archidiecezji Warmińskiej w Olsztynie, Archiwum Kapituły (dalej cyt. AAWO, AK), Dokumenty Kapituły, P 56 (= edycja: CDW, Bd. 3: Urkunden der Jahre 1376-1424 nebst Nachträgen, hrsg. v. Carl P. Woelky [Monumenta Historiae Warmiensis oder Quellensammlung zur Geschichte Ermlands, Abt. 1, Bd. 5], Braunsberg 1874, Nr. 199, s. 160-161). Dokument przywileju lokacyjnego wsi Stangiswalt (późniejszy niem. Polschendorf, ob. pol. Polska Wieś).

${ }^{49} \mathrm{~W}$ dokumencie komtura bałgijskiego Friedricha von Egloffstein z $13 \mathrm{~V} 1386$ r. znajduje się poświadczenie istnienia osady (wsi?) Petczinsdorf/Petzschendorff (niem. Pötschendorf, ob. pol. Pieckowo, 3,5 km NNW od Bezławek), której chronologii powstania nie można jednak dokładnie ustalić. Por. GStA PK, XX. HA, Perg.-Urk., Schieb. XXVI, Nr. 255 ( GStA PK, XX. HA, Ostpr. Fol. 124, fol. 106r). 
zoncie czasowym wzniesienia warowni bezławeckiej w odniesieniu do działań osiedleńczych prowadzonych w jej okolicach daje się zauważyć trzy podokresy: pierwszy - ok. 1360-1369 z wyłącznymi nadaniami na rzecz posiadaczy ziemskich, drugi - 1370-1378 z podobną intensywnością nadań ziemskich oraz akcją lokacji wsi czynszowych i wreszcie trzeci - 1379-1385, w którym działalność kolonizacyjna uległa wyraźnemu zastopowaniu.

Który zatem $\mathrm{z}$ owych trzech podokresów byłby najbardziej prawdopodobnym zakresem czasowym wzniesienia zamku w Bezławkach? Biorąc pod uwagę fakt, że to głównie wsie czynszowe jako znacznie liczebniejsze skupiska ludności aniżeli pojedyncze majątki ziemskie przyczyniły się do zwiększenia potencjału demograficznego obszarów w rejonie środkowej i dolnej Dajny, należałoby przypuszczać, że potrzeba uzupełnienia refugialnego potencjału istniejącego już zamku rastenburskiego pojawiła się na obszarach położonych na południe od tej warowni dopiero w trakcie drugiego podokresu, a zatem w ósmej dekadzie XIV w. Przy takiej interpretacji mielibyśmy do czynienia ze zjawiskiem wyprzedzenia budowy punktu fortyfikacyjnego z Bezławkach przez lokalną akcję osadniczą w okolicy, do której nowo napływająca ludność nie była jednak początkowo bynajmniej zupełnie pozbawiona warownej osłony. Osadnicy zakładający w latach siedemdziesiątych XIV stulecia nowe wsie czynszowe w rejonie dolnej i środkowej Dajny mieli bowiem w razie konieczności możliwość znalezienia tymczasowego schronienia w leżącym w odległości co najwyżej 1/2 dnia drogi (ok. 11/2 mili, czyli ok. 10-12 km) zamku w Rastenburgu ${ }^{50}$. Trzeba jednak uświadomić sobie, że wraz z postępującą akcją osadniczą w rejonie południowo-wschodniej i środkowej Barcji, tj. obszarów położonych dookoła Rastenburga, potencjał refugialny tej warowni w stosunku do okolicznej ludności nieustannie malał. Jest zatem prawdopodobne, że w ciągu ósmej dekady XIV w. komturzy bałgijscy, a może i kierownictwo zakonne z wielkim mistrzem na czele, skonstatowali konieczność budowy nowego zamku, który dzięki znacznym rozmiarom obwarowanego dziedzińca byłby $\mathrm{w}$ stanie istotnie odciążyć warownię rastenburską w funkcji zapewnienia miejsca schronienia dla ludności zwłaszcza mieszkającej w osadach położo-

${ }^{50}$ Por. Karte von Ost-Preussen nebst Preussisch Litthauen und West-Preussen nebst dem Netzdistrict. Aufgenommen unter Leitung des Königl. Preuss. Staatsministers Frey Herrn von Schrötter in den Jahren 1796 bis 1802 (dalej cyt. Schroetter), Staatsbibliothek zu Berlin Preußischer Kulturbesitz, Haus Unter den Linden, Kartensammlung (dalej cyt. SBB PK, HUdL, KS), Kart. N 1020, Bl. 48. Spośród wszystkich wskazanych 26 bądź 27 punktów osadniczych powstałych w rejonie środkowej i dolnej Dajny w latach [1360] 1364-1378 najdłuższą drogę do Rastenburga musieliby pokonać mieszkańcy dóbr Weissenen, położonych względem tego zamku w odległości $22 \mathrm{~km}$ w linii powietrznej i ok. 24-25 km (tj. ok. 3 mile) w terenie, jednak i tę trasę można było pokonać w ciągu jednego, najwyżej dwóch dni - jeżeli warunki pogodowe i terenowe były niesprzyjające. 
nych na południe i południowy zachód od niej, tj. w rejonie środkowego biegu Dajny.

W przeprowadzonej tu analizie można byłoby jednak założyć, że kierownictwo zakonne mogło podjąć decyzję o budowie zamku w Bezławkach już w siódmej dekadzie XIV stulecia, tj. w czasie, kiedy intensywna akcja osadnicza na omawianym obszarze dopiero rozpoczynała się, tak że warownia o znacznym potencjale refugialnym byłaby wówczas planowana $\mathrm{z}$ wyprzedzeniem w stosunku do działań kolonizacyjnych. Świadczyłoby to o dużych umiejętnościach braci zakonnych w perspektywicznym planowaniu w zakresie zagospodarowywania rozległych terenów, które było im zresztą przypisywane w starszej literaturze ${ }^{51}$. Sceptycznie do takich interpretacji nastawia wspomniany na wstępie dwukierunkowy charakter zależności między działaniami osadniczymi a budową punktów umocnionych. Analizy Wojciecha Brillowskiego $^{52}$ przeprowadzone dla zamku bezławeckiego wskazały orientacyjną minimalną liczbę obrońców, jakiej potrzebowała ta warownia do efektywnej obrony. Liczby tej wyłącznie mieszkający na zamku przynależący do Zakonu dinerzy i knechci zapewnić nie byli w stanie. Zatem okoliczni mieszkańcy - zarówno tzw. wolni, jak i ludność wieśniacza - stanowić musieli niezbędne uzupełnienie obsady warowni bezławeckiej ${ }^{33}$. Jeśli kierownictwo zakonne chciało uniknąć stosunkowo kosztownej praktyki ekspediowania kontyngentów zbrojnych do obsadzania dużych założeń obronnych położonych na obszarach niezagospodarowanych i tym samym pozbawionych zaplecza osadniczego i demograficznego ${ }^{54}$, $\mathrm{z}$ budową większego zamku musiało zazwyczaj czekać aż do podjęcia akcji osadniczej w jego najbliższej okolicy. Wydaje się więc, że rozmiary zamku bezławeckiego, wyraźnie przystosowane do funkcji refugialnej, zestawione z przeanalizowaną powyżej chronologią akcji osadniczej w rejonie dolnego i środkowego biegu Dajny, stanowią mocną przesłankę za przyjęciem chronologii wzniesienia tej warowni najwcześniej w ciągu lat siedemdziesiątych XIV w., kiedy ludność zamieszkująca funkcjonujące już w okolicy osady wiejskie dzięki swojemu potencjałowi liczbowemu była w stanie uzupełnić skład obsady zamku w sytuacjach największego zagrożenia.

${ }^{51}$ Por. Hans Mortensen, Landesplanung im ordenszeitlichen und herzoglichen Ostpreußen, Neues Archiv für Niedersachsen, H. 7-8: 1948, s. 439-459.

${ }^{52}$ W. BRILlOWSKI, op.cit., s. 121-130.

${ }^{53}$ Zwróciłem na to uwagę już w artykule z 2016 r. Por. K. Kwiatkowski, (Wild)haus $w$ Bezławkach, s. 13-14.

${ }^{54}$ Najlepiej poświadczonym źródłowo przykładem funkcjonowania tej praktyki w końcu XIV i w pierwszej ćwierci XV w. jest zamek ragnecki. Por. Krzysztof KwIATKowski, Zakon niemiecki jako „corporatio militaris”, cz. 1: Korporacja i krąg przynależacych do niej. Kulturowe i społeczne podstawy działalności militarnej zakonu w Prusach (do początku XV wieku) (Dzieje Zakonu Niemieckiego, t. 1), Toruń 2012, s. 128-129, 318, 414. 


\section{MOŻLIWE PRZYCZYNY BUDOWY ZAMKU BEZŁAWECKIEGO}

Przedstawiona interpretacja uściślająca możliwą chronologię powstania zamku w Bezławkach otwiera także pole analiz w kwestii okoliczności jego wzniesienia. Choć funkcja „obozowa” zamku, jako punktu zbiorczego wojska na wyprawy ofensywne na ziemie litewskie czy raczej ruskie, została przeze mnie zanegowana w $2016 \mathrm{r}^{55}$, to jednak znaczenie defensywne warowni jako punktu obronnego oraz miejsca schronienia ludności w przypadku najazdów litewskich nie ulega wątpliwości ${ }^{56}$. Mimo wszystko istnieją pewne przesłanki, by zagrożenie litewskimi akcjami militarnymi w procesie kształtowania się zamiarów, planów, a następnie podejmowania decyzji przez członków zakonu niemieckiego odnośnie do wzniesienia warowni bezławeckiej widzieć dopiero na pozycji drugorzędnej. Co innego zatem stanowić mogło istotną, jeśli wręcz nie główną pobudkę dla kierownictwa zakonnego do budowy zamku w Bezławkach?

Brak uściślonej i dającej się jednoznacznie zweryfikować chronologii wzniesienia warowni nakazuje nadzwyczajną ostrożność w budowaniu zależności i związków przyczynowo-skutkowych względem poświadczonych źródłowo pojedynczych wydarzeń tudzież całych ich ciągów. Niezależnie jednak od tego, czy budowa warowni przypadła na lata siedemdziesiąte - co wynika z analizy przeprowadzonej wyżej - czy może dopiero przełom ósmej i dziewiątej dekady XIV stulecia, obok powszechnie dostrzeganego czynnika „litewskiego" jeszcze jeden czynnik jawi się jako powód tej budowlanej inwestycji Zakonu. Jest nim mianowicie „kwestia warmińska”. Należy mianowicie rozważyć, czy znaczącym motywem wzniesienia zamku w Bezławkach nie była władcza rywalizacja między dwoma panami zajmującymi dominującą pozycję w kraju pruskim, tj. między zakonem niemieckim a biskupami warmińskimi ${ }^{57}$. W relacjach między warmińskimi hierarchami kościelnymi a braćmi zakonu niemieckiego to właśnie rejon, w którym założone zostały później Bezławki (wieś na prawie chełmińskim w $1371 \mathrm{r}$. i prawdopodobnie następnie zamek), tj. południowe rejony Barcji, zaczął stopniowo odgrywać od połowy lat dwu-

${ }^{55}$ K. KwiatKowski, (Wild)haus w Bezławkach, s. 14-19.

${ }^{56}$ Ibid., s. 14, 16.

${ }^{57} \mathrm{~W}$ kwestii relacji między obydwoma podmiotami władczymi w ciągu XIV w. por. Brigitte Poschmann, Bistümer und Deutscher Ordens in Preussen, 1243-1525. Untersuchung zur Verfassungs- und Verwaltungsgeschichte des Ordenslandes, Münster 1962, s. 34-35, 45-47, 53, 57-60, 69-71, 81, 85, 88-90, 92-100, 111-114 (tu też starsza literatura); ponadto również Alojzy Szorc, Dominium warmińskie 1243-1772. Przywilej i prawo chetmińskie na tle ustroju Warmii (Rozprawy i Materiały Ośrodka Badań Naukowych im. Wojciecha Kętrzyńskiego w Olsztynie, nr 112), Olsztyn 1990, s. 79-81; Jan PTAK, Wojskowość średniowiecznej Warmii (Rozprawy i Materiały Ośrodka Badań Naukowych im. Wojciecha Kętrzyńskiego w Olsztynie, nr 172), Olsztyn 1997, s. 65-72 (relacje na płaszczyźnie militarnej, także w odniesieniu do pierwszej połowy XV w.). 
dziestych XIV w. coraz większą rolę jako jeden z wielu czynników warunkujących interakcje między tymi obydwoma władczymi podmiotami.

Wspomniana kraina w $1326 \mathrm{r}$. została podzielona między nich ${ }^{58} \mathrm{i}$ wkrótce po tym roku nie tylko Zakon, lecz także biskupi warmińscy podjęli akcję osadniczą na tych obszarach barckich, rozciągających się w rejonie ówczesnej górnej Sajny i dalej na południowy zachód, które uznawali za sobie przydzielone. Intensywna aktywność warmińska w tym zakresie zaznacza się po ok. 1335/1340 r. ${ }^{59}$ i najprawdopodobniej znacznie wyprzedzała analogiczną działalność zakonu niemieckiego po drugiej stronie rozgraniczenia. Ośrodkiem centralnym stało się tu lokowane w $1337 \mathrm{r}$. miasto Reszel (niem. Rößel) ${ }^{60}$, zaś pewną osłonę i schronienie na wypadek wrogiego najazdu zapewniał obok dopiero wznoszonych obwarowań miejskich również drewniany wówczas zamek reszelski, wokół którego rozmieszczone zostały dobra lenników (castellani castri Resil) zobowiązanych do jego obrony ${ }^{61}$. Ataki wojsk książąt litewskich na omawiane okolice w 1345, 1347 i 1353 r. spowodowały, podobnie jak w części Barcji podlegającej zwierzchnictwu zakonu niemieckiego ${ }^{62}$, kilkuletni regres osadniczy, ale nie zatrzymały akcji osiedleńczych ${ }^{63}$. Jednocześnie dokonany

${ }^{58}$ Por. przyp. 10.

${ }^{59}$ Victor RöHrich, Die Kolonisation der Ermlandes, Kap. 8: Siedlungen in dem noch unaufgeteilten Gebiete während der Sedisvakanz (1334-1340), Zeitschrift für die Geschichte und Altertumskunde Ermlands, Bd. 19: 1916, s. 173-306; idem, Die Kolonisation der Ermlandes, Kap. 10: Siedlungen unter Bischof Hermann von Prag in den Gebieten des südöstlichen Ermlandes, die erst durch die Teilung von 1346 dem bischöflichen Tisch zufielen, Zeitschrift für die Geschichte und Altertumskunde Ermlands, Bd. 21: 1923, s. 277-337, 394-411, tu s. 277-337; Hans ScHMaUCH, Besiedlung und Bevölkerung des südlichen Ermlandes, Prussia. Zeitschrift für Heimatkunde und Heimatschutz, H. 30: 1932, s. 142-165, tu s. 142; sumarycznie zaś m.in. Georg MATERN, Burg und Amt Rößel. Ein Beitrag zur Burgenkunde des Deutschordenslandes, Königsberg 1925, s. 6-8.

${ }^{60}$ Adolf Poschmann, Rößel, [in:] Deutsches Städtebuch. Handbuch städtischer Geschichte (dalej cyt. DSB), Bd. 1: Nordostdeutschland, hrsg. v. Erich KeYser, Stuttgart-Berlin 1939, s. 101-102, tu s. 101; idem, 600 Jahre Rößel. Bilder aus alter und neuer Zeit: 1337-1937, Rößel 1937, s. 1-3; idem, Rößel, [in:] Ost- und Westpreussen, hrsg. v. Erich WeIse (Handbuch der historischen Stätten), Stuttgart 1981, s. 191-193, tu s. 192.

${ }^{61}$ Erwin Engelbrecht, Die Agrarverfassung des Ermlandes und ihre historische Entwicklung (Staats- und sozialwissenschaftliche Forschungen, H. 169), München-Leipzig 1913, s. 20; V. RöHrich, Die Kolonisation der Ermlandes, Kap. 8, s. 216-217; idem, Geschichte des Fürstbistums Ermland, s. 120; G. Matern, op.cit., s. 4-5; z nowszej literatury zaś A. Szorc, Dominium warmińskie, s. 193; J. РТAK, op.cit., s. 25.

${ }^{62}$ Por. wyżej s. 87-88.

${ }^{63}$ Victor RöHRICH, Die Kolonisation der Ermlandes, Kap. 9: Ortsgründungen unter Bischof Hermann von Prag in den Gebieten, die vor der Aufteilung des südöstlichen Ermlandes dem Bischof allein unterstanden, Zeitschrift für die Geschichte und Altertumskunde Ermlands, Bd. 20: 1919, s. 1-227; idem, Die Kolonisation der Ermlandes, Kap. 10, s. 277-337, 394-411; idem, Die Kolonisation der Ermlandes, Kap. 11: Die Ansetzungen des Bischofs Johann I, genannt von 
w 1346 r. podział terenów barckich uznawanych przez hierarchów warmińskich za podległe władztwu Kościoła warmińskiego między władztwo biskupie i władztwo kapitulne ${ }^{64}$ doprowadził do częściowego unormowania stosunków władczych w tym rejonie. Okolice Reszla przypadły wówczas biskupom, w rezultacie czego urzędujący od 1350 r. Johann I von Meißen (z Miśni) podjął niedługo po wstąpieniu na stolec biskupi budowę w Reszlu dużej murowanej warowni w miejscu dotychczasowego drewnianego zamku ${ }^{65}$. Prowadzona w kolejnej dekadzie przez wójtów biskupich, m.in. w okolicach rozciągających się na południe i południowy wschód od zamku reszelskiego, w rejonie rzek Młynówki i Wilczki, aktywność władcza spotkała się z postępującym - co zostało wyżej zaprezentowane - począwszy od tychże lat sześćdziesiątych XIV w. zainteresowaniem terenami leżącymi nieco dalej na wschód ze strony zakonu niemieckiego. Można w tym widzieć jeden $\mathrm{z}$ wielu aspektów zderzenia się aspiracji władczych obu stron w rejonach środkowej i południowo-zachodniej Barcji oraz na północno-zachodnich obszarach dawnej Galindii, które doprowadziło w czasach urzędowania Johanna II Stryprocka (1355-1373) do powstania konfliktu między obu stronami ${ }^{66}$. Victor Röhrich za główną przyczynę tej niezgody uznawał powołanie do życia przez kierownictwo zakonne urzę-

Meißen (1350-1355), Zeitschrift für die Geschichte und Altertumskunde Ermlands, Bd. 22: 1924, s. 1-38.

${ }^{64}$ Por. V. Röhrich, Geschichte des Fürstbistums Ermland, s. 138; H. Sснмauch, op.cit., s. 147, 196; Andrzej Radzimiński, Podziały kościelne, [in:] Państwo zakonu krzyżackiego w Prusach. Podzialy administracyjne i kościelne w XIII-XVI wieku, red. Zenon H. NowaK, Roman CzajA, Toruń 2000, s. 67-80, tu s. 75; idem, Podziały kościelne w Prusach, [in:] Zakon krzyżacki $w$ Prusach i Inflantach. Podzialy administracyjne i kościelne w XIII-XVI wieku, red. Roman CzAJA, Andrzej Radzimiński (Dzieje Zakonu Niemieckiego, t. 2), Toruń 2013, s. 107-128, tu s. 119; idem, Geneza oraz uksztattowanie się organizacji kościelnej (1206-1409), [in:] Państwo zakonu krzyżackiego w Prusach. Władza i społeczeństwo, red. Marian Biskup, Roman CzajA, Warszawa 2008, s. 143-176, tu s. 154; idem, Die Kirche im Deutschordensstaat in Preussen (1243-1525). Organisation, Ausstattung, Rechtsprechung, Geistlichkeit, Gläubige, übers. v. Liliana LewANDowSKA (Prussia Sacra, vol. 4), Toruń 2014, s. 29-30.

${ }^{65}$ BKDPOP, H. 4: Das Ermland, hrsg. v. Adolf Boettischer, Königsberg 1894, s. 213; G. Matern, op.cit., s. 9; Dehio, s. 531; Hanna DomańsKa, Zamek biskupów warmińskich w Reszlu, Rocznik Olsztyński, t. 8: 1968, s. 105-125, tu s. 109-110; Andrzej RzempoŁuch, Przewodnik po zabytkach sztuki dawnych Prus Wschodnich, Olsztyn 1992, s. 18; Ch. Herrmann, Mittelalterliche Architektur im Preussenland, s. 689.

${ }^{66} \mathrm{Nie}$ był to pierwszy spór między Zakonem a Kościołem warmińskim dotyczący uprawnień władczych na terenach Wielkiej Puszczy. Zachowane źródła poświadczają konflikt z przełomu lat trzydziestych i czterdziestych XIV w. dotyczący okolic pola Kurkosadel (późniejsza niem. wieś Kurken, ob. pol. Kurki) nad górną Łyną, zakończony traktatem z 26 VIII 1341 r. Por. Max Toeppen, Historisch-comparative Geographie von Preussen. Nach den Quellen, namentlich auch archivalischen, Gotha 1858, s. 127; idem, Die Theilung der Diözese Ermeland zwischen dem Deutschen Orden und dem ermländischen Bischofe, Altpreußische Monatsschrift, Bd. 3: 1866, s. 630-648, tu s. 641-642; V. RöHrIch, Die Theilung der Diözese Ermland, s. 249-251. 
du prokuratorskiego w Ortelsburgu (ob. pol. Szczytno), co według obecnego stanu badań miało miejsce pod koniec lat pięćdziesiątych XIV w. (być może w 1359 r. $)^{67}$. Warmiński kronikarz Johannes Plastwich wskazywał z perspektywy 100 lat na stronę zakonną jako inicjatora działań prowadzących do konfliktu, co miało mieć miejsce od początku lat sześćdziesiątych tego stulecia ${ }^{68}$. Sama datacja w kontekście przeanalizowanej wyżej akcji osadniczej Zakonu na obszarach południowej Barcji jest w zupełności wiarygodna. $Z$ drugiej jednak strony należy też zauważyć, że po zniszczeniach spowodowanych najazdami litewskimi na rejony „zakonnej” Barcji w latach 1345, 1347 i 1353, które wyraźnie zastopowały działania osadnicze miejscowych braci-urzędników w środkowej części Barcji i zmusiły Zakon do ograniczenia intensywności zarządu tymi okolicami, wraz z likwidacją w 1347 r. komturii leunenburskiej (sątoczeńskiej) ${ }^{69}$, kierownictwo zakonne mogło realnie obawiać się szybkiej ekspansji władczej biskupów warmińskich na tereny położone w rejonach bardzo ogólnie określonego jeszcze w 1251 i 1254 r. rozgraniczenia obszarów zakonnych i biskupich ${ }^{70}$, które poza krótkim odcinkiem powyżej źródeł Pasłęki bynajmniej nie zostało wcale uściślone ani w układzie z 1326 r., ani w kolejnej umowie z $1341 \mathrm{r}^{71}$

Tak więc obie strony miały konkretne ambicje władcze, które od początku lat sześćdziesiątych XIV w. m.in. w rejonie górnej i środkowej Dajny oraz środkowej Sajny zaczęły się ze sobą antagonistycznie spotykać. Ambicje te dotyczyły przede wszystkim przestrzeni gospodarczej (eksploatacja jezior, łowiectwo w lasach, pozyskiwanie z nich drewna, gospodarka pszczelarska, kuźnictwo, pozyskiwanie smoły, dziegciu i potażu). Przekazy dziekana kapituly warmińskiej Johannesa Plastwicha, w których przypisywał on Kościołowi warmińskiemu (biskupom i kapitule) m.in. zwierzchność nad szeregiem jezior

${ }^{67}$ V. RöHRICH, Die Theilung der Diözese Ermland, s. 253; odnośnie do prokuratorstwa ortelsburskiego (szczycieńskiego) por. S. JóźwiAK, Centralne i terytorialne organy władzy, s. 131-132.

${ }^{68}$ Die Denkschrift, [in:] Johannis Plastwici, Decani Warmiensis, Chronicon de vitis Episcoporum Warmiensium, hrsg. v. Carl P. Woelky (dalej cyt. Die Denkschrift), [in:] Scriptores rerum Warmiensium oder Quellenschriften zur Geschichte Ermlands (dalej cyt. SRW), Bd. 1, hrsg. v. Carl P. Woelky, Johann M. SAAge (Monumenta Historiae Warmiensis oder Quellensammlung zur Geschichte Ermlands, Abt. 2, Bd. 3), Braunsberg 1866, s. 10-137, edycja na s. 28-40, tu s. 28-29; Die Chronik, [in:] Johannis Plastwici, Decani Warmiensis, Chronicon de vitis Episcoporum Warmiensium, hrsg. v. Carl P. Woelky (dalej cyt. Die Chronik), [in:] ibid., s. 10-137, edycja na s. $41-137$, tu s. $62-67$.

${ }^{69}$ Por. wyżej s. 87-88.

${ }^{70}$ CDW, Bd. 1, Nr. 26, s. 47-49; CDW, Bd. 1, Nr. 31, s. 61-63; por. M. Toeppen, Die Theilung der Diözese Ermeland, s. 636-638; idem, Historia Mazur, s. 58-59; V. RöHrich, Die Theilung der Diözese Ermland, s. 218-224; A. Radzimiński, Podziały kościelne, s. 73-74; idem, Podziały kościelne w Prusach, s. 118.

${ }^{71}$ CDW, Bd. 2, Nr. 10, s. 11. 
położonych w rejonie rzeki Babant (Babięcka Struga, niem. Babant) ${ }^{72}$, a więc na obszarach leżących aż poza południowo-wschodnimi rubieżami Barcji, w ogólności oddają sytuację z siódmej dekady XIV stulecia, w przeciwnym bowiem razie niezrozumiała byłaby stanowcza reakcja zakonu niemieckiego, nawet jeśli w szczegółach mogły one stanowić odbicie roszczeń warmińskich hierarchów formułowanych w możliwie najszerszej postaci ${ }^{73}$. Istotnym aspektem uwiarygadniającym ich adekwatność do rzeczywistości lat sześćdziesiątych XIV w. jest fakt, że owe roszczenia dotyczyły w zasadzie praw do użytkowania jezior, a nie zakładania osad, nie mówiąc już o wsiach, a zatem odnosiły się do aktywności władczej realizowanej na obszarach ekstensywnie gospodarowanych, co odpowiadało ówczesnym realiom w tych rejonach.

Obok aspektu władczego ambicje obu stron miały również niewątpliwie wymiar symboliczny. Ze strony zakonu niemieckiego chodziło mianowicie o dążenie do podkreślenia jego dominującej pozycji w kraju pruskim i tym samym pewnych uprawnień zwierzchnich względem Kościoła warmińskiego i władztwa biskupów warmińskich, zaś ze strony tych ostatnich była to chęć zademonstrowania niezależności wobec Zakonu i jej realnego umacniania. W tym kontekście podjęta ok. 1350 r. budowa dużego murowanego obiektu warownego w Reszlu mogła być nie tylko działaniem biskupa Johanna I von Meißen przedsięwziętym na rzecz umocnienia ważnego punktu obronnego na drodze najazdów litewskich ze wschodu i południowego wschodu, lecz także podkreślać obecność władczą warmińskich hierarchów w tej części Barcji oraz ich polityczny potencjał i aspiracje. Taką zdecydowaną i opartą na pełnej samoświadomości pozycji w Prusach linię postępowania względem zakonu niemieckiego kontynuował również jego następca. O dążeniu Johanna II Stryprocka do zabezpieczenia nie tylko swoich świeckich praw w Prusach, lecz także umocnienia równorzędnego stanowiska w kraju względem wielkiego mistrza poprzez ostentację tytułu księcia Rzeszy rzymskiej, a więc władcy podległego jedynie cesarzowi, świadczy bulla imperatora Karola IV wystawiona dla tegoż biskupa w Burglins 20 VIII 1357 r. ${ }^{74}$ W ciągu siódmej dekady XIV w.

${ }^{72}$ Die Denkschrift, s. 28-29; Die Chronik, s. 65-66; owe akweny wymienia i identyfikuje M. Toeppen, Die Theilung der Diözese Ermeland, s. 639-640; idem, Historia Mazur, s. 88-89.

${ }^{73}$ Poświadczeniem tych pretensji jest pochodzący prawdopodobnie z końca XIV w. (sprzed 1423 r.) wykaz jezior, który w połowie XIX stulecia znajdował się w kodeksie nazywanym wówczas „ermländisches Privilegienbuch B” (obecnie: GStA PK, XX. HA, OF 80b; por. też SRW, Bd. 1, s. 28, przyp. a, s. 64-65, przyp. 26), z którego wydał go Johannes Voigt. Por. CDP, Bd. 4, hrsg. v. Johannes Voigt, Königsberg 1853, Nr. 76, s. 185-186 (wykazu tego nie ma obecnie w tym foliancie). Znał go w 1463 r. Johannes Plastwich (por. przyp. 72).

${ }^{74}$ CDW, Bd. 2, Nr. 256, s. 254-256 (regest: Regesta Imperii Online, http://www.regestaimperii.de/id/1357-08-20_1_0_8_0_0_3022_2690 [dostęp z 28 XII 2019 r.]). Obok tego także wystawiona tego samego dnia bulla potwierdzająca przywileje nadane biskupowi ze strony Stolicy Apostolskiej: CDW, Bd. 2, Nr. 257, s. 256-257 (regest: Regesta Imperii Online, 
konflikt między Zakonem a biskupem narósł do tego stopnia, że obie strony postanowiły go rozwiązać na drodze osobnego zjazdu obu władców. Spotkanie Winricha von Kniprode z Johannem II Stryprockiem w Neukirch (ob. pol. Podgrodzie), nieopodal Tolkmicka 24 VI 1369 r. nie tylko nie doprowadziło do ugody, ale w rezultacie afektywnego i impulsywnego zachowania się wielkiego mistrza (który posunął się do bezpośredniego ataku na swojego interlokutora) spór jeszcze zaostrzyło ${ }^{75}$. Strona warmińska postanowiła odwołać się do Stolicy Apostolskiej i wytoczyła Zakonowi proces kanoniczny. Problematyka ta jest w ogólności znana i nie ma tu potrzeby bardziej szczegółowo ją analizować ${ }^{76}$. U progu lat siedemdziesiątych doszło do zorganizowanych aktów przemocy zbrojnej ze strony Zakonu podejmowanych dowodnie przez komtura bałgijskiego przeciwko osadom i ludziom podlegającym zwierzchnictwu biskupa warmińskiego. Ostatecznie jednak kierownictwo zakonne nie zdecydowało się podjąć działań wojennych przeciwko dominium warmińskiemu, zaś cały spór obie strony zgodziły się oddać w 1372 r. pod rozstrzygnięcie sędziów arbitrażowych. Nowy biskup, Heinrich III Sorbom, wyznaczony

http://www.regesta-imperii.de/id/1357-08-20_2_0_8_0_0_3023_2691 [dostęp z 28 XII 2019 r.]). Por. M. Toeppen, Die Theilung der Diözese Ermeland, s. 643-644; V. RöHRICH, Die Theilung der Diözese Ermland, s. 253. Ten ostatni w działaniach biskupa widział przede wszystkim motywy obronne w relacjach z zakonem niemieckim. Z kolei A. Szorc wyraził opinię, jakoby kwestia tytułu książęcego hierarchów warmińskich aż po drugą połowę XVII w. była dla nich niewiele znacząca. Zob. A. Szorc, Dominium warmińskie, s. 40. Dokumenty cesarskie wskazują jednak, że były momenty, kiedy bezpośredni związek z Cesarstwem zyskiwał dla biskupów na znaczeniu, podkreślając ich niezależność i równorzędność względem wielkich mistrzów zakonu niemieckiego. W takim sensie wypowiedział się również Hans-Joachim Perk, Verfassungs- und Rechtsgeschichte des Fürstbistums Ermland, Königsberg i. Pr. 1931, s. 8. Zaś na znaczenie dążeń monarszych warmińskich hierarchów zwrócił uwagę już Jacob CARo, Geschichte Polens, Tl. 5, H. 1: 1455-1480, Gotha 1886, s. 415; za nim Hans SснмaUch, Der Streit um die Wahl des ermländischen Bischofs Lukas Watzenrode, Altpreußische Forschungen, Jg. 10: 1933, s. 65-101, tu s. 65, przyp. 1; wreszcie również B. Poschmann, op.cit., s. 113-114.

${ }^{75}$ M. Toeppen, Die Theilung der Diözese Ermeland, s. 645; V. RöHrich, Die Theilung der Diözese Ermland, s. 256-257; A. Radzimiński, Podziały kościelne, s. 74; idem, Podziały kościelne w Prusach, s. 118.

${ }^{76}$ Por. V. RöHrich, Die Theilung der Diözese Ermland, s. 257-266; idem, Geschichte des Fürstbistums Ermland, s. 165-172, 175-178; A. Szorc, Dominium warmińskie, s. 24-25; ostatnio zaś Alicja Dobrosielska, Spór biskupów warmińskich i kapituly z zakonem krzyżackim o granice dominium warmińskiego, [in:] Mniejszość i większość. Relacje kulturowe na pograniczach, cz. 1, red. Paweł Pietnoczka, Marek Radoch, Damian Szweda, Olsztyn 2016, s. 71-84, tu s. 73, 75, 81-82; por. także wcześniejsze uwagi Augusta Kolberga dotyczące okolic Reszla i późniejszej Świętej Lipki (niem. Heiligenlinde): August Kolberg, Geschichte der Heiligenlinde, Zeitschrift für die Geschichte und Altertumskunde Ermlands, Bd. 3: 1864-1866, s. 28-138, $435-520$, tu s. $47-52$. 
na następcę Johanna II przez papieża Grzegorza XI 5 IX 1373 r. zrezygnował z konfrontacyjnej postawy względem silniejszego i władczo, i propagandowo zakonu niemieckiego, decydując się na przyjęcie wyroku arbitrażowego wydanego po postępowaniu przeprowadzonym wedle uproszczonej teraz formuły. Zapadł on w Elblągu 28 VII 1374 r., zobowiązując obie strony do dokonania w ciągu najbliższej zimy 1374/1375 r. wspólnego przejazdu przez sporne tereny między słupem granicznym na polu Curchussadil/Kurkosadel (późniejsza wieś Kurken, ob. pol. Kurki) a lasem Krakotin (późniejsza osada Krakotin, ob. pol. Krakocin, ok. $5 \mathrm{~km}$ na wschód od Reszla i ok. $5 \mathrm{~km}$ na północny zachód od Bezławek) $)^{77}$. Oznaczało to wprawdzie w dalszym ciągu brak wyznaczonej jednoznacznie granicy na wspomnianym obszarze (tę należało dopiero wytyczyć w terenie), ale jednocześnie na nowo wyraźnie sygnalizowało zasięg biskupich uprawnień władczych w rejonach północno-zachodniej Galindii i południowej Barcji. Wyrok ów został potwierdzony przez papieża Grzegorza XI w Awinionie 16 II $1375 \mathrm{r}^{78}$, który dodatkowo podkreślając niezależność biskupa warmińskiego od władzy zakonu niemieckiego, polecił 28 marca tego roku biskupowi sambijskiemu Bartholomäusowi von Radam przekazać Heinrichowi III Sorbomowi apostolskie zezwolenie na nadawanie nowych lenn na niezagospodarowanych dotychczas terenach puszczańskich ${ }^{79}$, a więc w rejonach, których przynależność do dominium biskupiego mogła być uprzednio przez Zakon podważana. Długoletni konflikt został zakończony, ale nie zostały zlikwidowane zupełnie czynniki, które do niego doprowadziły. Tym bardziej że litera wyroku arbitrażowego nie została najprawdopodobniej wprowadzona w życie i zasądzony przejazd w terenie w celu wyznaczenia rozgraniczenia między władztwem biskupim i zakonnym się nie odbył. Po 1388 r., kiedy dokonane zostało rozgraniczenie $\mathrm{z}$ władztwem biskupim komornictwa olsztyńskiego jako części władztwa kapituły warmińskiejej ${ }^{80}$ ta ostatnia stała się kolejnym podmiotem w tych konfliktogennych relacjach. Granica w terenie została prawdopodobnie tylko częściowo wytyczona i opisana - przy tym w pewnych sektorach nadal bardzo ogólnie - dopiero w drugiej ćwierci XV stulecia,

${ }^{77}$ CDW, Bd. 2, Nr. 496, s. 513-517, tu zwłaszcza s. 516; CDW, Bd. 2, Nr. 497, s. 518-533, tu zwłaszcza s. 528-529; por. M. Toeppen, Historisch-comparative Geographie von Preussen, s. 129; idem, Die Theilung der Diözese Ermeland, s. 645-646; A. Szorc, Dominium warmińskie, s. 25; A. Dobrosielska, op.cit., s. 73-74; por. też przyp. 28 i 33.

${ }^{78}$ CDW, Bd. 2, Nr. 503, s. 540-542; por. V. Röнrich, Die Theilung der Diözese Ermland, s. 261; A. Szorc, Dominium warmińskie, s. 25.

${ }^{79}$ CDW, Bd. 2, Nr. 504, s. 542-543.

${ }^{80}$ V. RöHrich, Geschichte des Fürstbistums Ermland, s. 137; A. RAdZImiński, Podziały kościelne, s. 75; idem, Podziały kościelne w Prusach, s. 119; idem, Geneza oraz ukształtowanie się organizacji kościelnej, s. 154. 
mianowicie w $1428 \mathrm{r}^{81}$, następnie zaś jesienią $1447 \mathrm{r}^{82}$ oraz w lecie $1449 \mathrm{r} .{ }^{83}$ Trzeba tu więc wyraźnie podkreślić, że w połowie ósmej dekady XIV w. żadna ze stron nie była całkowicie pewna swojego panowania na omawianych obszarach, w tym także w rejonie na południe od lasu Krakotin ${ }^{84}$. Sytuacja obu

${ }^{81}$ AAWO, AK, Acta Capitularia S 1, fol. 46r-46v ( Acta capitularia per Mauritium episcopum confirmata anno 1537, AAWO, AK, Domarchiv Frbg. Schld. A Nr. 5, fol. 11v-13r (współczesnej sygnatury w AAWO nie udało się ustalić, więc źródło należy uznawać za zaginione) GStA PK, XX. HA, OF 80a, s. 19-22 = edycja: CDW, Bd. 4: Urkunden der Jahre 1424-35 und Nachträge, hrsg. v. Victor RöHrich, Franz LiedtKe, Hans SchmaUch [Monumenta Historiae Warmiensis oder Quellensammlung zur Geschichte Ermlands, Abt. 1, Bd. 9], Braunsberg 1935, Nr. 258, s. 290-293). Por. także Wiesław DŁUgokęCKI, Południowo-zachodnia granica komornictwa olsztyńskiego w pierwszej połowie XV w., [in:] Polska, Prusy, Ruś. Rozprawy ofiarowane prof. zw. dr hab. Janowi Powierskiemu w trzydziestolecie pracy naukowej, red. Błażej ŚLIwIŃsKI (Gdańskie Studia z Dziejów Średniowiecza, nr 2), Gdańsk 1995, s. 47-56, tu s. 48, 50, 53-56.

${ }^{82}$ Altt Zinsbuch des Hauses Elbing, Archiwum Państwowe w Gdańsku (dalej cyt. APG), 369,1 (Akta miasta Elbląga), nr 2102, fol. 75v (odnośnie do tego źródła por. M. ToEPPEN, Historisch-comparative Geographie von Preussen, s. 129-130; aczkolwiek z błędnymi danymi dotyczącymi sygnatury archiwalnej - dziewiętnastowieczna sygnatura owej „Starej księgi czynszów domu elbląskiego" brzmiała: „Stadt Elbing C 18”, a nie „A 18”); por. W. DŁUgokęCKI, Południowo-zachodnia granica, s. 48, 50-53. Istnieje także osiemnastowieczna kopia tego opisu. Por. APG, 369,1, nr 1305 (Zbiór odpisów dokumentów elbląskich, 1246-1477), s. 119-120.

${ }^{83}$ GStA PK, XX. HA, OF 80a, s. 9-13 ( GStA PK, XX. HA, OBA 10036, k. 1r-1v = edycja fragmentu: CDW, Bd. 4, s. 293); por. W. DŁUGOKĘCKI, Poludniowo-zachodnia granica, s. 48, 50, 53-56; ponadto A. DobrosielsKa, op.cit., s. 74-75.

${ }^{84} \mathrm{Na}$ marginesie należy tu wspomnieć o podejmowanych przez biskupów warmińskich w XVII-XVIII w. działaniach informacyjnych w Kurii Rzymskiej w kwestii obszaru diecezji (który w rezultacie likwidacji władztwa zakonu niemieckiego w 1525 r. został pomniejszony jedynie do terytorium dominium) czynionych w ramach dość regularnie składanych w ramach tzw. visitatio liminum relacji o stanie diecezji (relationes statuum, znane są relacje z lat 1604-1771). Por. Alojzy Szorc, Relacje biskupów warmińskich XVII i XVIII wieku do Rzymu o stanie diece$z j$, Studia Warmińskie, t. 5: 1968, s. 201-239; ostatnio w kwestii owych relationes por. także Irena MAKARCZYк, Warmia w okresie rządów biskupa Mikołaja Szyszkowskiego (1633-1643), Olsztyn 2017, s. 285-294 (tu też dalsza literatura). Niedawno bowiem A. Dobrosielska powołując się na wskazany wyżej artykuł A. Szorca, uznała fragmenty relationes dotyczące ograniczenia obszaru diecezji po 1525 r. za przejaw kontynuacji sporu warmińsko-zakonnego z XIV stulecia, teraz w warmińsko-pruskiej odsłonie. Zob. A. Dobrosielska, op.cit., s. 76, 82. Sam A. Szorc wypowiedział się w tej kwestii w taki sam sposób już w 1990 r., nie podając jednak żadnych konkretnych przykładów ewentualnych skarg zawartych w relationes statuum. Zob. A. SzorC, Dominium warmińskie, s. 25, przyp. 17. Już choćby najstarsza relatio z 1604 r. nie zawiera jakichkolwiek wzmianek o konfliktach czternastowiecznych, zaś kolejna relacja z $1610 \mathrm{r}$. jest raczej historycznym elaboratem o początkach i przeszłości diecezji, aniżeli świadectwem ówczesnego warmińsko-pruskiego sporu granicznego. Por. A. Szorc, Relacje biskupów, s. 213-214. Trzeba tu podkreślić, że wspominanie o dawnym konflikcie nie równa się przecież dążeniu do jego wznowienia w celu ewentualnej weryfikacji warunków, na jakich został on niegdyś zakończony. Podobną formę wspomnieniową ma wzmianka w przywoływanym przez A. Szorca (por. A. Szorc, Dominium warmińskie, s. 25, przyp. 17) liście kapituły warmińskiej do nuncjusza apostolskiego Vincenzo dal Portico z 18 VIII 1569 r. Zagadnienie to wymagałoby właściwie dokład- 
stron w tej kwestii zmieniła się częściowo dopiero w kolejnym dziesięcioleciu tegoż stulecia ${ }^{85}$.

W tak zarysowanym kontekście wydaje się, że budowę zamku bezławeckiego kierownictwo zakonne mogło podjąć przede wszystkim w celu umocnienia swojego zwierzchnictwa w ciągle jeszcze ostatecznie nierozgraniczonym rejonie kraju pruskiego. Wzniesienie murowanej warowni zaledwie nieco ponad milę $(8,5 \mathrm{~km})$ od biskupiego zamku w Reszlu miałoby wówczas szczególną wymowę i stanowiłoby wyraźną demonstrację gotowości Zakonu do hamowania ewentualnych ekspansywnych działań hierarchów warmińskich w tej okolicy, które po 1374/1375 r. wychodziłyby w jego opinii poza ogólnie wskazaną wówczas, aczkolwiek niezrealizowaną w terenie delimitację.

Powyższe rozważania skłaniają do konstatacji, że sugerowane przez Wojciecha Wółkowskiego i Wojciecha Brillowskiego, oparte na datacji dendrochronologicznej dwóch próbek drewna, czasowe umiejscowienie budowy zamku bezławeckiego na przełom lat siedemdziesiątych i osiemdziesiątych XIV w. (po 1377 r.) ${ }^{86}$ zyskuje na prawdopodobieństwie. Można w tym dziele fortyfikacyjnym widzieć środek kontroli przez zakon niemiecki działań biskupów warmińskich w rejonie lasu Krakotin stworzony właściwie bezpośrednio po zakończonym, ale bynajmniej nie zlikwidowanym konflikcie. Kierownictwo zakonne zyskiwało w tej nowej warowni symboliczną, ale i zarazem fizyczną gwarancję ugruntowania władztwa zakonnego we wspomnianej okolicy ${ }^{87}$, a w ostateczności także istotne narzędzie do dalszego powstrzymania ewentualnej ekspansji władczej Heinricha III Sorboma w kierunku środkowej i górnej Dajny, jeśliby biskup z jakichś przyczyn nie dostosował się do tenoru zatwierdzonego przez papieża wyroku arbitrażowego ${ }^{88}$.

Trzeba również zauważyć, że datowanie budowy zamku w Bezławkach na czas ok. 1377 r. zaprezentowaną tu „warmińską” interpretację przyczyn jego wzniesienia jeszcze pośrednio wzmacnia. Chodzi w tym przypadku o układ

niejszego przebadania. Z kolei zachowane z początku XVI w. opisy fragmentów linii granicznej między terytorium dominium a władztwem zakonu niemieckiego (por. GStA PK, XX. HA, OBA 18121, k. 1r-1v; GStA PK, XX. HA, OBA 18398, k. 1r, 2r; GStA PK, XX. HA, OBA 18399, k. 1r) wraz ze sporządzonym 29 III 1503 r. opisem objazdu granicy dominium z okręgami ortelsburskim (szczycieńskim), nidzickim i olsztyneckim (por. GStA PK, XX. HA, OBA 18799, k. 1r-2v) wskazują raczej, że po 1449 r. delimitacja prusko-warmińska nadal była obiektem obustronnych uściśleń tudzież korekt.

${ }^{85}$ Por. przyp. 98.

${ }^{86}$ Por. przyp. 25 i 26.

${ }^{87}$ Symboliczną funkcję zamków podkreślał stosunkowo niedawno Joachim Zeune, Burgen - Symbole der Macht. Ein neues Bild der mittelalterlichen Burg, Darmstadt 1997, s. 42-48.

${ }^{88}$ Zamek bezławecki prawdopodobnie blokował wyjście ze strony Reszla w kierunku na południowy wschód, co wynika z prawdopodobnego układu późnośredniowiecznej sieci drożnej (por. Schroetter, Bl. 48), aczkolwiek kwestia ta wymaga dokładniejszych badań osadniczych i szerzej historyczno-geośrodowiskowych. 
sieci komunikacyjnej. Otóż rozwijająca się, począwszy od ok. 1360 r., akcja osadnicza w południowo-wschodnich okolicach Barcji w rejonie dolnego i środkowego biegu Dajny w ciągu nieco ponad dekady spowodowała przesunięcie się zachodniego skraju Wielkiej Puszczy w tej okolicy kilka mil na wschód w kierunku Rynu (niem. Rhein), gdzie w 1377 r. rozpoczęła się budowa murowanego zamku ${ }^{89}$, zapewne $\mathrm{w}$ miejscu dotychczas funkcjonującej warowni o charakterze wildhausu ${ }^{90}$. Około $20 \mathrm{~km}$ na południowy zachód już wcześniej wzniesiony został drewniany najprawdopodobniej zamek w Szestnie (niem. Seehesten), pośrednio poświadczony źródłowo $\mathrm{w} 1371 \mathrm{r} .^{91}$, być może wzniesiony (według szesnastowiecznej tradycji narracyjnej) w 1348 r. ${ }^{92}$, a który

${ }^{89}$ Wigand, cap. 94d, s. 584; za tą wzmianką M. Toeppen, Historisch-comparative Geographie von Preussen, s. 205; BKDPOP, H. 6: Masuren, hrsg. v. Adolf BoETTischer, Königsberg 1896, s. 83-84; Heß von WichdorfF, Beträge zur Geschichte der Ordenschlosses Rhein und der Stadt Rhein im Kreise Lötzen in Masuren, Masovia, H. 31: 1926, s. 111-153, tu s. 113 (z niewiadomych przyczyn pisze o wzniesieniu zamku ok. 1376 r., przy czym nie rozróżnia pierwotnej budowli drewnianej od późniejszej murowanej); Dehio, s. 526-527; Max MeYнöfer, Rhein, [in:] Ost- und Westpreussen, hrsg. v. Erich WeIse (Handbuch der historischen Stätten), Stuttgart 1981, s. 187-188, tu s. 187; T. Torbus, Die Konventsburgen, s. 236-239, 609-614; idem, Zamki konwentualne, s. 270, 272-273; Ch. Herrmann, Mittelalterliche Architektur im Preussenland, s. 678. Według szacunków T. Torbusa intensywne prace budowlane trwały najpóźniej do 1422 r., aczkolwiek nie ma na to żadnych architektonicznych przesłanek ani bezpośrednich wzmianek w źródłach pisanych.

${ }^{90}$ Wskazywałyby na to wyniki fragmentarycznych badań archeologicznych przeprowadzonych w obrębie założenia zamkowego w latach 1983-1984 (por. T. TorbUs, Die Konventsburgen, s. 237, przyp. 1077, s. 612; idem, Zamki konwentualne, s. 270, przyp. 1029), w czasie których w północno-zachodnim narożu obecnej budowli odkryto starszy od niej fragment kamiennego muru. Niewykluczone, że warownia funkcjonująca w Rynie przed 1377 r. miała postać niedużego murowanego domu zamkowego bądź typu wieżowego bądź kamienicowego. Są to jednak tylko dywagacje. Możliwość kontynuacji badań i weryfikacji hipotez dotyczących starszego założenia zamkowego została ostatecznie utracona w pierwszej dekadzie XXI stulecia, kiedy przeprowadzono gruntowną restaurację współcześnie stojącej budowli i przekształcono ją w hotel.

${ }^{91}$ Wigand, cap. 81, s. 571; por. M. ToEPPEN, Historisch-comparative Geographie von Preussen, s. 205; idem, Historia Mazur, s. 96; Fritz StOMвer, Haus Seehesten, [in:] Unsere masurische Heimat. Zum hundertjährigen Bestehen des Kreises Sensburg, hrsg. v. Karl Templin, Sensburg 1926, s. 117-122, tu s. 118; P. GLAss, op.cit., s. 62.

${ }^{92}$ Caspar Hennenberger, Ercleru[n]g der Preussischen grössern Landtaffel oder Mappen, Königsperg i. Pr. 1595, s. 434; Ch. M. HARTKNoch, op.cit., s. 425; za nimi m.in. Johannes VoIGT, Geschichte Preussens von den ältesten Zeiten bis zum Untergange der Herrschaft des Deutschen Ordens, Bd. 5: Die Zeit vom Hochmeister Ludolf König von Weizau 1342 bis zum Tode des Hochmeisters Konrad von Wallenrod 1393, Königsberg 1832, s. 78; por. też Max MeYHöFER, Seehesten, [in:] Ost- und Westpreussen, hrsg. v. Erich Weise (Handbuch der historischen Stätten), Stuttgart 1981, s. 210. Fritz Stomber kładł budowę pierwszej warowni w Szestnie na 1348/1349 r., a ponadto przyjął rok 1367 jako moment rozpoczęcia prac budowalnych przy nowym, murowanym zamku, co nie znajduje jakiegokolwiek poświadczenia źródłowego, choć nie jest nieprawdopodobne. Zob. F. Stomber, Die erste Besiedlung, s. 122; idem, Haus Seehesten, s. 118; podobnie również P. Glass, op.cit., s. 62; por. także G. LeYding, op.cit., s. 195. 
zapewne między ok. 1350 a ok. 1370 r. (a może nieco później?) został przekształcony w budowlę murowaną ${ }^{93}$. Aczkolwiek poźnośredniowieczna sieć drożna w południowo-wschodniej części Barcji nie została dotychczas w szczegółach rozpoznana, na podstawie nowożytnego materiału kartograficznego wydaje się, że obydwie te warownie osłaniały główne szlaki wiodące w kierunku Rastenburga z obszaru Wielkiej Puszczy (niem. Große Wildnis), po których mogły poruszać się wojska książąt litewskich, mianowicie trasę z południowego wschodu zapewne wiodącą od brodu w Eckersbergu (ob. pol. Okartowo) i trakt z południa mający zapewne dwie odnogi, jedną idącą z Johannisburga (stpol. Jańsbork, ob. pol. Pisz), drugą zaś (poświadczoną źródłowo być może od połowy XIV w. i określaną w końcu tego stulecia mianem heerweg) prowadzącą od strony mazowieckiej Wizny i następnie Kamiennego Brodu na Skrodzie przez obszary puszczańskie nad środkową Krutynią i dalej na północ ${ }^{94}$. Bezławki położone były na uboczu tej drogi wiodącej z Szestna do Rastenburga, będącej zapewne przedłużeniem heerwegu od początków XV w. docierającego do nowo lokowanego wówczas Sensburga (stpol. Ządźbork, ob. pol. Mrągowo $)^{95}$, która na szerokości geograficznej bezławeckiego zamku prawdo-

${ }_{93}^{93}$ BKDPOP, H. 6, s. 99-100; Dehio, s. 582; Ch. HerrmanN, Mittelalterliche Architektur im Preussenland, s. 726-727; Jan SALm, Szestno, [in:] Leszek KaJZer, Stanisław KoøodZIEJSKi, Jan SALM, Leksykon zamków w Polsce, red. Leszek KaJZer, Warszawa 2001, s. 480.

${ }^{94}$ Mapa Jana Władysława Suchodolca z lat 1732-1739: General-Carte von dem Königreich Preussen, SBB PK, HUdL, KS, Kart. N 9784/3, Bl. 9-10 ( fragment mapy J. W. Suchodolca: Ein Teil der Ämter Angerburg, Barten, Gerdauen, Insterburg, Masuren, Oletzko, Preußische Eylau, Rastenburg und Seehesten, GStA PK, XX. HA, Allgemeine Kartensammlung des Staatsarchiv Königsberg [dalej cyt. AKSSAK], B 10.054); Schroetter, Bl. 48, 55-56, 62-63, 69-70. Odnośnie do tego heerwegu por. Elżbieta Kowalczyк, Szlaki drogowe w puszczy na pograniczu mazowiecko-pruskim w średniowieczu, Kwartalnik Historyczny, R. 106: 1999, nr 1, s. 3-17, tu s. 4-5; eadem, Dzieje granicy mazowiecko-krzyżackiej (między Drwęca a Pisa), Warszawa 2003, s. 74.

${ }^{95}$ Miasto $\mathrm{w}$ połowie XVw. było umocnione i posiadało przynajmniej dwie bramy. Por. Amtsbücher des Deutschen Ordens um 1450. Pflegeamt zu Seehesten und Vogtei zu Leipe (dalej cyt. ABDOPSVL), hrsg. u. bearb. v. Cordula A. Franzke, Jürgen Sarnowsky, (Beihefte zum Preußischen Urkundenbuch, Bd. 3), Göttingen 2015, s. 137; por. też Józef JudziŃsKI, $Z$ dziejów Mragowa, [in:] Mragowo. Z dziejów miasta i powiatu, red. Andrzej WaKar, Olsztyn 1975, s. 63-111, tu s. 69 (pisał o południowej „Bramie Szczycieńskiej” i północnej „Bramie Kętrzyńskiej”). Przechodziły przez nie trasy w kierunku Rastenburga i Ortelsburga (Szczytna). Por. Jan Gancewski, Roman Czaja, Historia i rozwój przestrzenny Mragowa, [in:] Mragowo, opr. hist. Jan Gancewski, Roman Czaja, opr. kart. Dariusz ChwiaŁkowski, Radosław Golba, Zenon Kozię, Agnieszka M. Noryśkiewicz, Agnieszka Pilarska (Atlas Historyczny Miast Polskich, t. 3: Mazury, z. 3), Toruń 2016, s. 5-12, tu s. 6 (którzy jednak uznawali, że miasto było pozbawione umocnień); por. także plan miasta Mrągowa z ok. 1700 r.: Samuel von Suchodoletz, Grundriß wie die churfürstl[iche] den 24. Juni 1698 abgebrandte Stadt Sensburg soll wiederumb in Gottes nahmen auffgebauet und in auffnehmen gebracht werden, GStA PK, XX. HA, AKSSAK, G 10.348b (= reprodukcja w pomniejszeniu 0,91: Mragowo, opr. hist. Jan GANCEWSKI, Roman CzajA, opr. kart. Dariusz ChwiaŁkowski, Radosław Golba, Zenon Kozie£, Agnieszka M. Noryśkiewicz, Agnieszka Pilarska [Atlas Historyczny Miast Polskich, t. 3: Mazury, z. 3], 
podobnie zbliżała się do doliny Dajny, ale jej nie przekraczała ${ }^{96}$. Przechodził natomiast nieopodal warowni odgałęziający się w tamtejszej okolicy trakt na Reszel, którego przeprawa na Dajnie znajdowała się zapewne na południowo-zachodnim krańcu siedliska lokowanej w 1371 r. wsi Bezławki ${ }^{97}$. Jeśli więc zamek miałby stanowić w pierwszym rzędzie punkt umocniony na jednym ze szlaków najazdów litewskich, to osłaniałby on przede wszystkim trakt wiodący na obszar dominium biskupów warmińskich. W kontekście wspomnianego konfliktu warmińsko-zakonnego $\mathrm{z}$ lat sześćdziesiątych i początku lat siedemdziesiątych XIV w. nie sposób przypuszczać, że w kierownictwie zakonnym mogłaby się wówczas pojawić chęć wzmocnienia osłony terenów rywalizującego z Zakonem i antagonistycznie nastawionego doń władcy. Po zakończeniu tego konfliktu w połowie ósmej dekady tegoż stulecia takie działania byłyby już zupełnie zrozumiałe, tym bardziej, jeśli uwzględnić wcześniejszą koncepcję dominującej funkcji refugialnej warowni bezławeckiej.

Jest bardzo prawdopodobne, że wraz z pewnym unormowaniem relacji sąsiedzkich w rejonie lasu Krakotin i środkowego biegu Dajny między stroną warmińską i zakonną, co wyraźnie nastąpiło najpóźniej w drugiej połowie lat osiemdziesiątych XIV stulecia $^{98}$, dominujące w trakcie powstawania warowni

Toruń 2016, mapa 5b). Odnośnie do przebiegu odcinka tego szlaku między Sensburgiem a Rastenburgiem por. Władysław SzULIST, Ważniejsze ladowe szlaki handlowo-komunikacyjne Warmii i Mazur w XVI-XVIII wieku, Komunikaty Mazursko-Warmińskie, 1972, nr 2-3 (116-117), s. $297-318$, tu s. 309 (aczkolwiek w zasadzie tylko na podstawie dokumentacji kartograficznej mapy Schroettera).

${ }^{96}$ SBB PK, HUdL, KS, Kart. N 9784/3, Bl. 9-10 ( GStA PK, XX. HA, KS, B 10.054); ponadto: Ostpreußen, um 1770, GStA PK, XI. Hauptabteilung (dalej cyt. XI. HA), Allgemeine Kartensammlung (dalej cyt. AKS), A 50.126, Tl. 2; Charte von Westpreußen, um 1795, GStA PK, XI. HA, AKS, A 50.224; Schroetter, Bl. 48, 55.

${ }^{97}$ SBB PK, HUdL, KS, Kart. N 9784/3, Bl. 9-10 ( GStA PK, XX. HA, AKSSAK, B 10.054); GStA PK, XI. HA, AKS, A 50.126, Tl. 2; Schroetter, Bl. 48. Tej trasy nie uwzględnił W. Szulist, jednak na jej istnienie w drugiej połowie XIV w. mógłby wskazywać dostosowany do przebiegu tejże drogi układ siedliska wsi Bezławki będący zarówno w połowie XVII w., jak i w końcu XVIII w. formą ulicówki (zob. W. Szulist, op.cit., s. 297-318; por. mapę Józefa Naronowicza-Narońskiego z ok. 1660-1676r.: Distictus Rastenborgensis in Ducatu Prussiae eiusque tract Bartoniae, GStA PK, XX. HA, AKSSAK, F 10.328; także Schroetter, Bl. 48), oczywiście przy założeniu trwałości układu osadniczego między drugą połową XIV a połową XVII w., jak również funkcjonowanie we wsi w 1422 r. aż dwóch karczem. Por. Das Grosse Zinsbuch des Deutschen Ordens (1414-1438), hrsg. v. Peter G. Thielen, Marburg 1958, s. 69; por. także S. SzczepańSKI, op.cit., s. 26.

${ }^{98}$ Pośrednim dowodem na to jest delimitacja terytoriów ortelsburskiego (szczycieńskiego) i szestneńskiego przeprowadzona w 1387 r., którą potwierdził dokument Konrada Zöllnera von Rotenstein z 27 VII 1387 r. Por. GStA PK, XX. HA, OF 270a, fol. 19r-20r ( GStA PK, XX. HA, OF 270a, fol. 106r [inna foliacja: 54r] GStA PK, XX. HA, OF 271, fol. 187v-188v [stara foliacja: 183v-184v] GStA PK, XX. HA, OF 186, k. 5r-5v = edycja z tej podstawy rękopiśmiennej: ABDOPSVL, s. 42-44). Por. też P. GLAss, op.cit., s. 134. Dokładne wyznaczenie granic dwóch okręgów w rejonach puszczańskich przylegających przy tym do obszaru dominium warmiń- 
bezławeckiej - niejako pierwotne - funkcje, mianowicie: markująca aspiracje władczo-kontrolne zakonu niemieckiego w okolicy oraz demonstrująca jego siłę i lokalny potencjał władczy, mające bezpośrednie odniesienie względem pobliskiego sąsiada warmińskiego, jak również refugialna pełniona względem okolicznej ludności, zostały uzupełnione przez początkowo mniej ważną funkcję obronną związaną z kolei z odległym sąsiadem litewskim, który w tym właśnie okresie, począwszy od dziewiątej dekady XIV w., traktowany był przez Zakon za coraz groźniejszy.

\section{BIBLIOGRAFIA}

Andrzejewski, Aleksander and Leszek Kajzer. "Castle at Sątoczno in 'terra Barthensi' or praise of history." In Castella Maris Baltici, vol. 7: Beiträge der Tagung 'Die Stadt als Burg. Architektur-, rechts- und sozialhistorische Aspekte befestigter Städte im Ostseeraum vom Mittelalter bis zur frühen Neuzeit', 03.-06. September 2003 in Greifswald, edited by Felix Bierman, Matthias Müller and Christofer Herrmann, 9-14. Greifswald: [s.n.], 2006.

Andrzejewski, Aleksander and Leszek Kajzer. "Sątoczno i Sępopol. Dwa modele rozwoju osadnictwa." In Pogranicze polsko-pruskie i krzyżackie, vol. 2, edited by Kazimierz Grążawski, 275-285. Włocławek, Brodnica: Oficyna Wydawnicza Włocławskiego Towarzystwa Naukowego „Lega”, 2007.

Andrzejewski, Aleksander and Leszek Kajzer. "Sprawozdanie z badań archeologicznoarchitektonicznych przeprowadzonych na terenie zamku w Sątocznie, gm. Korsze, woj. warmińsko-mazurskie w 2001 roku." Łódzkie Sprawozdania Archeologiczne 7 (2001): 289-307.

Andrzejewski, Aleksander and Leszek Kajzer. "Z badań Instytutu Archeologii Uniwersytetu Łódzkiego nad zamkami na terenie województwa warmińsko-mazurskiego." In Pogranicze polsko-pruskie i krzyżackie, edited by Kazimierz Grążawski, 227-233. Włocławek, Brodnica: Oficyna Wydawnicza Włocławskiego Towarzystwa Naukowego „Lega”, 2003.

Andrzejewski, Aleksander and Leszek Kajzer. “Zamek krzyżacki w Sątocznie, gm. Korsze w świetle badań terenowych w 2002 roku.” Łódzkie Sprawozdania Archeologiczne 8 (2002/2003): 237-251.

Andrzejewski, Aleksander and Leszek Kajzer. “Zamek w Sątocznie w 'Terra Barthensi' albo triumf historii." In XIV Sesja Pomorzoznawcza, vol. 2: Od wczesnego średniowiecza do czasów nowożytnych, edited by Henryk Paner and Mirosław Fudziński, 197-204. Gdańsk: Muzeum Archeologiczne, 2005.

Antoni, Michael, ed. Dehio-Handbuch der Kunstdenkmäler West- und Ostpreußen. Die ehemaligen Provinzen West- und Ostpreußen (Deutschordensland Preußen) mit Bütower und Lauenburger Land. München, Berlin: Deutscher Kunstverlag, 1993.

skiego oznaczało bowiem, że w tym czasie kierownictwo zakonne uznało za właściwe podjęcie intensywniejszej akcji osadniczej na tych terenach, co z kolei wskazuje, że traktowało rozgraniczenie sprzed 13 lat za pewne i niepodważalne. 
Arszyński, Marian. “Architektura warowna zakonu krzyżackiego w Prusach.” In Fundacje artystyczne na terenie państwa krzyżackiego w Prusach. Katalog wystawy w Muzeum Zamkowym w Malborku 25 czerwca - 12 września 2010 roku, vol. 2: Eseje, edited by Barbara Pospieszna, 7-45. Malbork: Muzeum Zamkowe, 2010.

Arszyński, Marian. “Deutschordensburg." In Lexikon des Mittelalters, vol. 2: Bettlerwesen bis Codex von Valencia, 914-917. Stuttgart, Weimar: Artemis Verlag, 1983.

Arszyński, Marian. Budownictwo warowne zakonu krzyżackiego w Prusach (1230-1454). Toruń: Uniwersytet Mikołaja Kopernika, 1995.

Bartlett, Robert. Tworzenie Europy. Podbój, kolonizacja i przemiany kulturowe 950-1350. Translated by Grażyna Waluga. Poznań: Poznańskie Towarzystwo Przyjaciół Nauk, 2003.

Beckherrn, Carl. "Das Ordenshaus Bäslack.” Altpreußische Monatsschrift 21 (1884): 637-649.

Beckherrn, Carl. "Verzeichniss der die Stadt Rastenburg betreffenden Urkunden." Altpreußische Monatsschrift 22 (1885): 505-605.

Benninghoven, Friedrich. "Die Burgen als Grundpfeiler des spätmittelalterlichen Wehrwesens im preußisch-livländischen Deutschordenstaat." In Die Burgen im deutschen Sprachraum. Ihre rechts- und verfassungsgeschichtliche Bedeutung, part 1, edited by Hans Patze, 565-601. Sigmaringen: Thorbecke, 1976.

Berns, Wolf-Rüdiger. Burgenpolitik und Herrschaft des Erzbischofs Balduin von Trier (1307-1354). Sigmaringen: Thorbecke, 1980.

Boettischer, Adolf, ed. Die Bau- und Kunstdenkmäler der Provinz Ostpreußen, vol. 2: Natangen. Königsberg: Verlag von Bernhard Teichert, 1898.

Boettischer, Adolf, ed. Die Bau- und Kunstdenkmäler der Provinz Ostpreußen, vol. 3: Das Oberland. Königsberg: Verlag von Bernhard Teichert, 1893.

Boettischer, Adolf, ed. Die Bau- und Kunstdenkmäler der Provinz Ostpreußen, vol. 4: Das Ermland. Königsberg: Verlag von Bernhard Teichert, 1894.

Boettischer, Adolf, ed. Die Bau- und Kunstdenkmäler der Provinz Ostpreußen, vol. 6: Masuren. Königsberg: Verlag von Bernhard Teichert, 1896.

Bosl, Karl. Europa im Aufbruch. Herrschaft - Gesellschaft - Kultur vom 10. bis zum 14. Jahrhundert. München: Beck, 1980.

Brillowski, Wojciech and Arkadiusz Koperkiewicz. "Archaeological and Art History Research in Bezławki: Analysis of Form and Function of Small Castle Architecture in the Eastern Part of Teutonic Order's Lands." In Castella Maris Baltici, vol. 10: Finland 24-29.8.2009. Raseborg, Olavinlinna and Häme Castles, edited by Kari Uotila, Terhi Mikkola and Anna-Maria Vilkuna, 33-43. Saarijärven: Suomen keskiajan arkeologian seura, 2012.

Brillowski, Wojciech. “Analiza funkcjonalna założenia obronnego w Bezławkach.” In Bezławki - ocalić od zniszczenia. Wyniki prac interdyscyplinarnych prowadzonych w latach 2008-2011, edited by Arkadiusz Koperkiewicz, 119-135. Gdańsk: Wydawnictwo Uniwersytetu Gdańskiego, 2013.

Caro, Jacob. Geschichte Polens, vol. 5/1: 1455-1480. Gotha: Friedrich Andreas Perthes, 1886.

Clasen, Karl H. Die mittelalterliche Kunst im Gebiete des Deutschordensstaates Preußen, vol. 1: Die Burgbauten. Königsberg i. Pr.: Gräfe und Unzer, 1927. 
Długokęcki, Wiesław. "Kolonizacja ziemi chełmińskiej, Prus i Pomorza Gdańskiego do 1410 r." In Państwo zakonu krzyżackiego w Prusach. Władza i społeczeństwo, edited by Marian Biskup and Roman Czaja, 200-217. Warszawa: Wydawnictwo Naukowe PWN, 2008.

Długokęcki, Wiesław. "Odbudowa osadnictwa, kolonizacji i przemiany wsi w państwie krzyżackim (1411-1525).” In Państwo zakonu krzyżackiego w Prusach. Władza i społeczeństwo, edited by Marian Biskup and Roman Czaja, 375-383. Warszawa: Wydawnictwo Naukowe PWN, 2008.

Długokęcki, Wiesław. "Południowo-zachodnia granica komornictwa olsztyńskiego w pierwszej połowie XV w." In Polska, Prusy, Ruś. Rozprawy ofiarowane prof. $z w$. $d r$ hab. Janowi Powierskiemu $w$ trzydziestolecie pracy naukowej, edited by Błażej Śliwiński, 47-56. Gdańsk: Wydawnictwo „Marpress”, 1995.

Dobrosielska, Alicja. "Spór biskupów warmińskich i kapituły z zakonem krzyżackim o granice dominium warmińskiego.” In Mniejszość i większość. Relacje kulturowe na pograniczach, vol. 1, edited by Paweł Pietnoczka, Marek Radoch and Damian Szweda, 71-84. Olsztyn: Instytut Historii i Stosunków Międzynarodowych Uniwersytetu Warmińsko-Mazurskiego, 2016.

Domańska, Hanna. “Zamek biskupów warmińskich w Reszlu.” Rocznik Olsztyński 8 (1968): 105-125.

Engelbrecht, Erwin. Die Agrarverfassung des Ermlandes und ihre historische Entwicklung. München, Leipzig: Duncker \& Humblot, 1913.

Erlen, Peter. Europäischer Landesausbau und mittelalterliche deutsche Ostsiedlung. Ein struktureller Vergleich anhand von drei exemplarisch ausgewählten Siedelregionen. Marburg/Lahn: J. G. Herder-Institut, 1992.

Fehrenbach, Bernd. Die Burgenpolitik der Landgrafen von Hessen im Spätmittelalter (1263-1413). Marburg: Selbstverlag des Hessischen Landesamtes für Geschichtliche Landeskunde, 2012.

Gancewski, Jan and Roman Czaja. "Historia i rozwój przestrzenny Mrągowa." In Mragowo, edited by Jan Gancewski, Roman Czaja, Dariusz Chwiałkowski, Radosław Golba, Zenon Kozieł, Agnieszka M. Noryśkiewicz and Agnieszka Pilarska, 5-12. Toruń: Wydawnictwo Naukowe Uniwersytetu Mikołaja Kopernika, 2016.

Glaß, Paul. "Unsere Heimat zur Zeit des Deutschen Ordens." In Der Kreis Sensburg, edited by Fritz Bredenberg, 59-78. Würzburg: Holzner, 1960.

Haftka, Mieczysław. Zamki krzyżackie w Polsce. Szkice z dziejów. Malbork: Muzeum Zamkowe, Płock: Wydawnictwo Consort, 1999.

Hechberger, Werner. Adel, Ministerialität und Rittertum im Mittelalter. München: Oldenbourg, 2004.

Herrmann, Christofer. Burgen im Ordensland. Deutschordens- und Bischofsburgen in Ost-und Westpreußen. Ein Reisehandbuch. Würzburg: Bergstadtverlag Korn, 2006.

Herrmann, Christofer. Mittelalterliche Architektur im Preussenland. Untersuchungen zur Frage der Kunstlandschaft und -geographie. Petersberg: Michael Imhof Verlag, Olsztyn: Atres, 2007.

Herwig, Ebner. "Die Burg als Forschungsproblem mittelalterlicher Verfassungsgeschichte." In Die Burgen im deutschen Sprachraum. Ihre rechts- und verfassungsgeschichtliche Bedeutung, part 1, edited by Hans Patze, 11-82. Sigmaringen: Thorbecke, 1976. 
Higounet, Charles. Die deutsche Ostsiedlung im Mittelalter. Translated by Mafred Vasold. Berlin: Siedler, 1986.

Jóźwiak, Sławomir. "Przekształcenia administracyjne na południowo-wschodnich rubieżach państwa krzyżackiego w latach czterdziestych XIV wieku." Komunikaty Mazursko-Warmińskie (1999) issue 1: 3-14.

Jóźwiak, Sławomir. Centralne i terytorialne organy władzy zakonu krzyżackiego w Prusach w latach 1228-1410. Rozwój - przekształcenia - kompetencje. Toruń: Wydawnictwo Naukowe Uniwersytetu Mikołaja Kopernika, 2012.

Jóźwiak, Sławomir and Janusz Trupinda. "Die Bauchronologie und das Raumprogramm der Deutschordensburg Barten (Barciany) im Lichte mittelalterlicher Schriftquellen." Ordines Militares Colloquia Torunensia Historica: Yearbook for the Study of the Military Orders 23 (2018): 301-338.

Jóźwiak, Sławomir and Janusz Trupinda. Krzyżackie zamki komturskie w Prusach. Topografia i układ przestrzenny na podstawie średniowiecznych źródeł pisanych. Toruń: Wydawnictwo Naukowe Uniwersytetu Mikołaja Kopernika, 2012.

Judziński, Józef. “Z dziejów Mrągowa.” In Mragowo. Z dziejów miasta i powiatu, edited by Andrzej Wakar, 63-111. Olsztyn: Wydawnictwo Pojezierze, 1975.

Kasiske, Karl. Die Siedlungstätigkeit des Deutschen Ordens im östlichen Preußen bis zum Jahre 1410. Königsberg i. Pr.: Gräfe und Unzer, 1934.

Kerber, Dieter. "Burgenpolitik." In Burgen in Mitteleuropa. Ein Handbuch, vol. 2: Geschichte und Burgenlandschaften, 73-78. Darmstadt: Theiss, 1999.

Kerber, Dieter. "Die Burg als Element des Landesausbaues." In Burgen in Mitteleuropa. Ein Handbuch, vol. 2: Geschichte und Burgenlandschaften, 68-72. Darmstadt: Theiss, 1999.

Kerber, Dieter. "Die Burg als Herrschaftszentrum." In Burgen in Mitteleuropa. Ein Handbuch, vol. 2: Geschichte und Burgenlandschaften, 82-89. Darmstadt: Theiss, 1999.

Kętrzyński, Wojciech. O ludności polskiej w Prusiech niegdyś krzyżackich. Edited by Grzegorz Białuński. Olsztyn: Ośrodek Badań Naukowych im. W. Kętrzyńskiego, Towarzystwo Naukowe im. W. Kętrzyńskiego, 2009.

Kittel, Piotr. "Rekonstrukcja systemu fos zamku krzyżackiego w Sątocznie, w gminie Korsze, w świetle sondowań geologicznych.” Łódzkie Sprawozdania Archeologiczne 8 (2002/2003): 253-263.

Klimek, Robert. "Między prawdą a zmyśleniem... Trzy błędy historyczne z dziejów Reszla.” In Reszel. 680 lat historii miasta, edited by Grzegorz Białuński and Robert Klimek, 213-238. Reszel: Towarzystwo Miłośników Reszla i Okolic, 2018.

Kolberg, August. "Geschichte der Heiligenlinde." Zeitschrift für die Geschichte und Altertumskunde Ermlands 3 (1864-1866): 28-138, 435-520.

Koperkiewicz, Arkadiusz. “Zamek w Bezławkach w świetle badań archeologicznych.” In Bezławki - ocalić od zniszczenia. Wyniki prac interdyscyplinarnych prowadzonych w latach 2008-2011, edited by Arkadiusz Koperkiewicz, 44-74. Gdańsk: Wydawnictwo Uniwersytetu Gdańskiego, 2013.

Kowalczyk, Elżbieta. "Szlaki drogowe w puszczy na pograniczu mazowiecko-pruskim w średniowieczu." Kwartalnik Historyczny 106/1 (1999): 3-17.

Kowalczyk, Elżbieta. Dzieje granicy mazowiecko-krzyżackiej (między Drwęca a Pisa). Warszawa: DiG, 2003. 
Kwiatkowski, Krzysztof. “(Wild)haus w Bezławkach (Bayselauken, Bäslack) - uwagi na temat budownictwa warownego zakonu niemieckiego w późnośredniowiecznych Prusach.” Zapiski Historyczne 81/2 (2016): 7-44.

Kwiatkowski, Krzysztof. "Bezławki - kilka uzupełnień źródłowych dotyczących późnośredniowiecznego zespołu osadniczego na obrzeżach kraju pruskiego." Komunikaty Mazursko-Warmińskie (2016) issue 1: 31-53.

Kwiatkowski, Krzysztof. Zakon niemiecki jako 'corporatio militaris', vol. 1: Korporacja $i$ krag przynależących do niej. Kulturowe i społeczne podstawy działalności militarnej zakonu w Prusach (do początku XV wieku). Toruń: Wydawnictwo Naukowe Uniwersytetu Mikołaja Kopernika, 2012.

Leyding, Gustaw. “Dzieje wsi." In Mrągowo. Z dziejów miasta i powiatu, edited by Andrzej Wakar, 137-216. Olsztyn: Wydawnictwo Pojezierze, 1975.

Makarczyk, Irena. Warmia w okresie rząów biskupa Mikołaja Szyszkowskiego (1633-1643). Olsztyn: Wydawnictwo Uniwersytetu Warmińsko-Mazurskiego w Olsztynie, 2017.

Matern, Georg. Burg und Amt Rößel. Ein Beitrag zur Burgenkunde des Deutschordenslandes. Königsberg: Verlag von Bernhard Teichert, 1925.

Maurer, Hans-Martin. "Burgen.” In Die Zeit der Staufer. Geschichte - Kunst - Kultur. Katalog der Ausstellung, vol. 3: Aufsätze, 119-128. Stuttgart: Württembergisches Landesmuseum Stuttgart, 1977.

Meyhöfer, Max. "Rhein." In Ost- und Westpreussen, edited by Erich Weise, 187-188. Stuttgart: Alfred Kröner Verlag, 1981.

Meyhöfer, Max. "Seehesten." In Ost- und Westpreussen, edited by Erich Weise, 210. Stuttgart: Alfred Kröner Verlag, 1981.

Mortensen, Hans. "Landesplanung im ordenszeitlichen und herzoglichen Ostpreußen." Neues Archiv für Niedersachsen 7-8 (1948): 439-459.

Mühling, [s.n.]. "Statistische und andere Notizen aus einer alten Amtsrechnung aus Sehisten.” Neue Preußische Provinzial-Blätter. Andere Folge 3 (1853): 220-229, 259-270.

Ottersbach, Christian. Die Burgen der Herren und Grafen von Hanau (1166-1642). Studien zur Burgenpolitik und Burgenarchitektur eines Adelshauses. Neustadt/Aisch: Verlag Ph. C. W. Schmidt, 2018.

Patze, Hans. "Die Burgen in Verfassung und Recht des deutschen Sprachraumes." In Die Burgen im deutschen Sprachraum. Ihre rechts- und verfassungsgeschichtliche Bedeutung, part 2, edited by Hans Patze, 421-441. Sigmaringen: Thorbecke, 1976.

Perk, Hans-Joachim. Verfassungs- und Rechtsgeschichte des Fürstbistums Ermland. Königsberg i. Pr.: Kopal \& Schulz, 1931.

Pilecka, Elżbieta, Zbigniew Nawrocki, Romualda Uziembło and Jadwiga Łukaszewicz, eds. Zamek krzyżacki w Toruniu XIII-XXI w. Studium historyczno-architektoniczne z katalogiem detalu architektonicznego ze zbiorów Muzeum Okręgowego. Toruń: Muzeum Okręgowe, 2017.

Poschmann, Adolf. “Rößel." In Deutsches Städtebuch. Handbuch städtischer Geschichte, vol. 1: Nordostdeutschland, edited by Erich Keyser, 101-102. Stuttgart, Berlin: W. Kohlhammer Verlag, 1939.

Poschmann, Adolf. “Rößel.” In Ost- und Westpreussen, edited by Erich Weise, 191-193. Stuttgart: Alfred Kröner Verlag, 1981. 
Poschmann, Adolf. 600 Jahre Rößel. Bilder aus alter und neuer Zeit: 1337-1937. Rößel: Selbstverlag der Stadtverwaltung, 1937.

Poschmann, Brigitte. Bistümer und Deutscher Ordens in Preussen, 1243-1525. Untersuchung zur Verfassungs- und Verwaltungsgeschichte des Ordenslandes. Münster: Westfälische Wilhelms-Universität zu Münster, 1962.

Powierski, Jan. Prusowie, Mazowsze i sprowadzenie Krzyżaków do Polski, vol. 2/1. Malbork: Muzeum Zamkowe, 2001.

Ptak, Jan. Wojskowość średniowiecznej Warmii. Olsztyn: Ośrodek Badań Naukowych im. W. Kętrzyńskiego, 1997.

Radzimiński, Andrzej. "Geneza oraz ukształtowanie się organizacji kościelnej (1206-1409)." In Państwo zakonu krzyżackiego w Prusach. Władza i społeczeństwo, edited by Marian Biskup and Roman Czaja, 143-176. Warszawa: Wydawnictwo Naukowe PWN, 2008.

Radzimiński, Andrzej. “Podziały kościelne w Prusach.” In Zakon krzyżacki w Prusach i Inflantach. Podziały administracyjne i kościelne w XIII-XVI wieku, edited by Roman Czaja and Andrzej Radzimiński, 107-128. Toruń: Wydawnictwo Naukowe Uniwersytetu Mikołaja Kopernika, 2013.

Radzimiński, Andrzej. “Podziały kościelne.” In Państwo zakonu krzyżackiego w Prusach. Podziały administracyjne i kościelne w XIII-XVI wieku, edited by Zenon H. Nowak and Roman Czaja, 67-80. Toruń: Towarzystwo Naukowe w Toruniu, Wydawnictwo Naukowe Uniwersytetu Mikołaja Kopernika, 2000.

Radzimiński, Andrzej. Die Kirche im Deutschordensstaat in Preussen (1243-1525). Organisation, Ausstattung, Rechtsprechung, Geistlichkeit, Gläubige. Translated by Liliana Lewandowska. Toruń: Wydawnictwo Naukowe Uniwersytetu Mikołaja Kopernika, 2014.

Rogge, Adolf. "Das älteste Urkunde über die Familie Sparwin vom 22. Decbr. 1375." Altpreußische Monatsschrift 12 (1875): 377-378.

Röhrich, Victor. "Die Kolonisation der Ermlandes, Kap. 8: Siedlungen in dem noch unaufgeteilten Gebiete während der Sedisvakanz (1334-1340)." Zeitschrift für die Geschichte und Altertumskunde Ermlands 19 (1916): 173-306.

Röhrich, Victor. "Die Kolonisation der Ermlandes, Kap. 9: Ortsgründungen unter Bischof Hermann von Prag in den Gebieten, die vor der Aufteilung des südöstlichen Ermlandes dem Bischof allein unterstanden." Zeitschrift für die Geschichte und Altertumskunde Ermlands 20 (1919): 1-227.

Röhrich, Victor. "Die Kolonisation der Ermlandes, Kap. 10: Siedlungen unter Bischof Hermann von Prag in den Gebieten des südöstlichen Ermlandes, die erst durch die Teilung von 1346 dem bischöflichen Tisch zufielen." Zeitschrift für die Geschichte und Altertumskunde Ermlands 21 (1923): 277-337, 394-411.

Röhrich, Victor. "Die Kolonisation der Ermlandes, Kap. 11: Die Ansetzungen des Bischofs Johann I, genannt von Meißen (1350-1355)." Zeitschrift für die Geschichte und Altertumskunde Ermlands 22 (1924): 1-38.

Röhrich, Victor. "Die Theilung der Diözese Ermland zwischen dem deutschen Orden und dem ermländischen Bischofe." Zeitschrift für die Geschichte und Altertumskunde Ermlands 12 (1897-1899): 217-266.

Röhrich, Victor. Geschichte des Fürstbistums Ermland. Braunsberg: Druck und Verlag der Ermländischen Zeitungs und Verlagsdruckerei, 1925. 
Rzempołuch, Andrzej. Przewodnik po zabytkach sztuki dawnych Prus Wschodnich. Olsztyn: Agencja Wydawnicza „Remix”, 1992.

Salm, Jan. "Kętrzyn.” In Leszek Kajzer, Stanisław Kołodziejski and Jan Salm. Leksykon zamków w Polsce, edited by Leszek Kajzer, 223-225. Warszawa: Arkady, 2001.

Salm, Jan. "Szestno." In Leszek Kajzer, Stanisław Kołodziejski and Jan Salm. Leksykon zamków w Polsce, edited by Leszek Kajzer, 480. Warszawa: Arkady, 2001.

Schmauch, Hans. "Besiedlung und Bevölkerung des südlichen Ermlandes." Prussia. Zeitschrift für Heimatkunde und Heimatschutz 30 (1932): 142-165.

Schmauch, Hans. "Der Streit um die Wahl des ermländischen Bischofs Lukas Watzenrode." Altpreußische Forschungen 10 (1933): 65-101.

Schubert, Ernst. Fürstliche Herrschaft und Territorium im späten Mittelalter. München: Oldenbourg, 2006.

Schulze, Hans K. Grundstrukturen der Verfassung im Mittelalter, vol. 2: Familie, Sippe und Geschlecht, Haus und Hof, Dorf und Mark, Burg, Pfalz und Königshof, Stadt. Stuttgart, Berlin, Köln: Kohlhammer, 2000.

Sikorski, Jerzy. "Kętrzyn średniowieczny." In Kętrzyn. Dzieje miasta, edited by Stanisław Achremczyk, 85-152. Kętrzyn: Kętrzyńskie Centrum Kultury, Miejska Biblioteka Publiczna im. W. Kętrzyńskiego, Olsztyn: Ośrodek Badań Naukowych im. W. Kętrzyńskiego, 2016.

Sikorski, Jerzy. “Sątoczno. Geneza i funkcje zamku oraz charakter osady.” Warmińsko-Mazurski Biuletyn Konserwatorski 1 (1999): 63-83.

Spławska-Korczak, Maria. Zamek krzyżacki w Świeciu. Próba rekonstrukcji zamku wysokiego w średniowieczu. Torun: Wydawnictwo Naukowe Uniwersytetu Mikołaja Kopernika, 2014.

Stomber, Fritz. "Die erste Besiedlung des Kreises Sensburg." In Unsere masurische Heimat. Zum hundertjährigen Bestehen des Kreises Sensburg, edited by Karl Templin, 122-133. Sensburg: Selbstverlag des Kreisausschusses, 1926.

Stomber, Fritz. "Haus Seehesten." In Unsere masurische Heimat. Zum hundertjährigen Bestehen des Kreises Sensburg, edited by Karl Templin, 117-122. Sensburg: Selbstverlag des Kreisausschusses, 1926.

Szczepański, Seweryn. "Bezławki i okolice w kontekście osadniczym plemiennej Barcji oraz kętrzyńskiego okręgu prokuratorskiego w średniowieczu.” In Bezławki ocalić od zniszczenia. Wyniki prac interdyscyplinarnych prowadzonych $w$ latach 2008-2011, edited by Arkadiusz Koperkiewicz, 14-37. Gdańsk: Wydawnictwo Uniwersytetu Gdańskiego, 2013.

Szorc, Alojzy. "Relacje biskupów warmińskich XVII i XVIII wieku do Rzymu o stanie diecezji." Studia Warmińskie 5 (1968): 201-239.

Szorc, Alojzy. Dominium warmińskie 1243-1772. Przywilej i prawo chetmińskie na tle ustroju Warmii. Olsztyn: Wydawnictwo Pojezierze, 1990.

Szulist, Władysław. "Ważniejsze lądowe szlaki handlowo-komunikacyjne Warmii i Mazur w XVI-XVIII wieku.” Komunikaty Mazursko-Warmińskie (1972) issue 2-3: 297-318.

Toeppen, Max. "Die Theilung der Diözese Ermeland zwischen dem Deutschen Orden und dem ermländischen Bischofe." Altpreußische Monatsschrift 3 (1866): 630-648. 
Toeppen, Max. Historia Mazur. Przyczynek do dziejów krainy i kultury pruskiej. Translated by Małgorzata Szymańska-Jasińska. Olsztyn: Wspólnota Kulturowa „Borussia", 1995.

Toeppen, Max. Historisch-comparative Geographie von Preussen. Nach den Quellen, namentlich auch archivalischen. Gotha: Justus Perthes, 1858.

Torbus, Tomasz. Die Konventsburgen im Deutschordensland Preußen. München: Oldenbourg, 1998.

Torbus, Tomasz. Zamki konwentualne państwa krzyżackiego w Prusach. Gdańsk: Fundacja Terytoria Książki, Słowo/Obraz Terytoria, 2014.

Torbus, Tomasz. Zamki krzyżackie. Translated by Łukasz Bieniasz. Wrocław: Zakład Narodowy im. Ossolińskich, 2010.

Voigt, Johannes. Geschichte Preussens von den ältesten Zeiten bis zum Untergange der Herrschaft des Deutschen Ordens, vol. 5: Die Zeit vom Hochmeister Ludolf König von Weizau 1342 bis zum Tode des Hochmeisters Konrad von Wallenrod 1393. Königsberg: Gebrüder Bornträger, 1832.

Wakuluk, Lidia. "Osadnictwo i sieć parafialna kętrzyńskiego okręgu prokuratorskiego w XIV-XV wieku.” Komunikaty Mazursko-Warmińskie (1976) issue 3: 375-394.

Ważny, Tomasz. "Analiza dendrochronologiczna drewna z zamku w Bezławkach (woj. warmińsko-mazurskie).” In Bezławki - ocalić od zniszczenia. Wyniki prac interdyscyplinarnych prowadzonych w latach 2008-2011, edited by Arkadiusz Koperkiewicz, 272-273. Gdańsk: Wydawnictwo Uniwersytetu Gdańskiego, 2013.

Wenskus, Reinhard. "Das Ordensland Preußen als Territorialstaat des 14. Jahrhundert." In Der deutsche Territorialstaat im 14. Jahrhundert, vol. 1, edited by Hans Patze, 347-382. Sigmaringen: Thorbecke, 1970.

Wenskus, Reinhard. "Das Ordensland Preußen als Territorialstaat des 14. Jahrhundert." In Reinhard Wenskus. Ausgewählte Aufsätze zum frühen und preußischen Mittelalter. Festgabe zu seinem 70. Geburtstag, edited by Hans Patze, 317-352. Sigmaringen: Thorbecke, 1986.

Wichdorff von, Heß. "Beträge zur Geschichte der Ordenschlosses Rhein und der Stadt Rhein im Kreise Lötzen in Masuren.” Masovia 31 (1926): 111-153.

Wiewióra, Marcin, ed. Zamek biskupów chetmińskich w Wąbrzeźnie w świetle badań archeologiczno-architektonicznych. Studia i materiały. Toruń: Wydawnictwo Naukowe Uniwersytetu Mikołaja Kopernika, 2014.

Wiewióra, Marcin, ed. Zamek w Grudziądzu w świetle badań archeologiczno-architektonicznych. Studia i materiały. Toruń: Instytut Archeologii Uniwersytetu Mikołaja Kopernika, Grudziądz: Urząd Miejski, 2012.

Wółkowski, Wojciech. “Architektura zamku w Bezławkach.” In Bezławki - ocalić od zniszczenia. Wyniki prac interdyscyplinarnych prowadzonych $w$ latach 2008-2011, edited by Arkadiusz Koperkiewicz, 109-117. Gdańsk: Wydawnictwo Uniwersytetu Gdańskiego, 2013.

Zeune, Joachim. Burgen - Symbole der Macht. Ein neues Bild der mittelalterlichen Burg. Darmstadt: Pustet, 1997. 